\title{
CRUSADING AND HOLY WAR IN THE TEUTONIC ORDER'S STRUGGLE FOR ŽEMAITIJA. WRITTEN AND VISUAL PERSPECTIVES
}

\author{
Gregory Leighton \\ https://orcid.org/0000-0002-4203-2313
}

\begin{abstract}
In the late 14th and early 15th centuries, the region of Žemaitija (Samogitia) was still contested between the Teutonic Knights and the Grand Dukes of Lithuania. Its conquest and conversion were the final objective of the Teutonic Order's campaigns in the southern Baltic region. The article assesses the language and ideology of crusading and holy war concerning the conquest of Žemaitija, as reflected in selected correspondence from the period by the Teutonic Order. It begins with a historical overview of the problem, along with a brief outline of the donations of Žemaitija to the Teutonic Knights at the end of the 14th and the beginning of the 15th century. Following this, the paper outlines the use of specific themes from the crusading movement in the 14th century in Prussia, before examining the presence (or lack thereof) of these elements concerning Žemaitija. Other specific themes are identified and discussed concerning the ideological expression of the Teutonic Order's mission and image in its external correspondence, one being the depiction of Žemaitija as the end of Christendom (daz ende der cristenheit). This article suggests that this was an attempt to fit the conquests into a broader framework: Žemaitija was depicted as the successor to the Order's earlier wars against the Prussians. Finally, the article discusses the presence of this imagery in the visual culture of the Ordensland, particularly in Königsberg Cathedral and its surrounding pilgrimage churches.

KEY WORDS: Teutonic Order; Žemaitija; holy war; Baltic Crusades; later Crusades; crusading ideology; visual culture of Prussia.
\end{abstract}

\begin{abstract}
ANOTACIJA
XIV a. pabaigoje - XV a. pradžioje Vokiečių ordino riteriai ir Lietuvos didieji kunigaikščiai tebesivaržė dèl Žemaitijos. Jos nukariavimas ir krikštas buvo Vokiečių ordino kampanijų pietiniame Baltijos jūros regione galutinis tikslas. Straipsnyje analizuojamos retorika ir ideologija, taikytos kryžiaus žygių ir šventojo karo metu, siekiant užkariauti Žemaitiją, ir atsiskleidžiančios šio laikotarpio Vokiečių ordino rinktinèje korespondencijoje. Straipsnio pradžioje pateikiama klausimo istorinè apžvalga ir užsimenama apie Žemaitijos užrašymus Vokiečių ordinui XIV a. pabaigoje ir XV a. pradžioje. Toliau aptariami konkretūs siužetai, kuriuos kryžiaus žygių judejjimas eksploatavo Prūsijoje XIV a., ir gilinamasi kiek (ir ar) šie siužetai buvo taikomi ir Žemaitijai. Kiti konkretūs siužetai nustatyti ir aptarti nagrinejjant Vokiečiu ordino misijos ir vaizdinio ideologinę raišką jo išorinejje korespondencijoje; vienas jų vaizdavo Žemaitiją kaip krikščionijos pakrašti (daz ende der cristenheit). Straipsnis suponuoja, kad tai buvo bandymas parodyti užkariavimus platesniame kontekste - Žemaitiją siekta vaizduoti kaip ankstesnių Ordino karų prieš prūsus „,jpèdinę“. Galiausiai straipsnyje analizuojamos šios vaizduotès apraiškos Vokiečių ordino valdų Prūsijoje vizualiojoje kultūroje, ypač Karaliaučiaus katedroje ir aplinkinèse piligrimų lankytose bažnyčiose. PAGRINDINIAI ŽODŽIAI: Vokiečių ordinas; Žemaitija; šventasis karas; kryžiaus žygiai Baltijos regione; vèlyvieji kryžiaus žygiai; kryžiaus žygių ideologija; Prūsijos vizualioji kultūra.
\end{abstract}

Gregory Leighton, PhD in History, Team Member on the Malbork Castle Museum's Research Project, Styl Piękny w redakcji czeskiej w Prusach - Rzeźba kamienna z lat 1380-1400, Starościńska 1, PL-82-200 Malbork, Poland; 3269 Dovecote Drive, Quakertown, PA, US-18951, United States. E-mail: gregjleighton@gmail.com. 


\section{Background}

The conquest and conversion of Žemaitija were the final objective of the Teutonic Order's campaigns in the southern Baltic region. From the perspective of 19th and 20th-century historiography, these campaigns were viewed in terms of political and economic expansion on the part of the Teutonic Order. For example, the successful conquest of Žemaitija would link up the holdings of the Teutonic Order in Livonia and Prussia, forming a land bridge between the two parts of the Ordensland in Livonia and Prussia. ${ }^{1}$ In this sense, the Order's campaigns alongside Vytautas, the Grand Duke of Lithuania, to conquer Žemaitija have been framed primarily in terms of expansionist politics and economic motivations on the part of the Teutonic Knights. ${ }^{2}$ It certainly appears to have been a major reason for the conquest of the region in the 14th century, and we can glean this from the charter sources concerning the donation of Žemaitija to the Order by Vytautas. The Treaty of Dubysa, issued on 31 October 1382, was the first time that Žemaitija was described and granted to the Order. ${ }^{3}$ The region was contested between the Order and the Grand Dukes of Lithuania, Vytautas and Jogaila, with the Order siding with Vytautas with the Treaty of Königsberg, on 13 January $1384 .{ }^{4}$ This treaty was nullified by July. Vytautas granted Žemaitija to the Order two more times, in the Treaty of Sallinwerder $(1398)^{5}$ and the Treaty of Raciąż (1404). ${ }^{6}$

Clearly, the land between Prussia and Livonia formed an important element to the Order's political, spiritual and economic motivations and ambitions in the 15th century. However, the recent work of Sebastian Kubon has illuminated the complex nature of this extended period of conquest and conversion in Žemaitija. ${ }^{7}$ This work has aided in subsequent scholars moving away from earlier interpretations and placing the goal of continued conversion at the forefront of the external politics of the Order in the late 14th and early 15th century. Far from a black and white narrative

NÖBEL, Wilhelm. Das Problem der Einrichtung der Ordensvogtei Samaiten. Zeitschrift für Ostforschung, 1968, 17. Jhg., Hf. 4, S. 692-697.

2 For example, KRUMBHOLTZ, Robert. Samaiten und der Deutsche Orden bis zum Frieden am Melno-See. Königsberg, 1890.

3 Codex epistolaris Vitoldi magni ducis Lithuaniae 1376-1430 (Monumenta medii aevi historica res gestas Poloniae illustrantia, t. VI). Ed. Antonii PROCHASKA. Cracoviae, 1882 (hereafter, CEVMDL), p. 1, No 4 [=Codex diplomaticus Lithuaniae. Ed. by Eduardus RACZYŃSKI. Vratislaviae, 1845, p. 57-58, Cap. III, No 4; Codex Diplomaticus Prussicus. Urkunden-Sammlung zur ältern Geschichte Preussens (hereafter, CDP). Bd. 4. Hrsg. von Johannes VOIGT. Königsberg, 1853, S. IV in Regesten.

4 CEVMDL, p. 3-4, No 13. 30 January1384, in Königsberg.

5 Ibid, p. 55, No 187, No 188 [= Liv-, Esth- und Curländisches Urkundenbuch. Bd. 4. Hrsg. von Friedrich Georg von BUNGE. Reval, 1859, Sp. 218-227, Nr. 1478-1479].

6 Ibid, p. 96-97, No 285. Also see Geheimes Staatsarchiv Preußischer Kulturbesitz, XX. HA, OF 3, p. 63/133, for information on this treaty between the Order and Vytautas.

7 KUBON, Sebastian. Die Außenpolitik des Deutschen Ordens unter Hochmeister Konrad von Jungingen (13931407) (Nova Mediaevalia, Bd. 15). Göttingen, 2016, especially S. 58-59. 
centring around territorial and economic expansion, the vast body of written materials collected and analysed by Kubon, from charters and chronicles to personal correspondence, highlights the importance of spreading Christianity as opposed to grabbing land and linking Prussia and Livonia. This can especially be demonstrated in the relationship between the Order and Vytautas, who participated alongside one another in the war against the enemies of the faith for mutual benefit, highlighting the multi-faceted nature of relations between the Teutonic Order and Lithuania, as well as the benefits of accepting Christianity for personal and political aspirations. ${ }^{8}$ As expressed in the Treaty of Marienwerder at Vilnius (14 June 1384), in exchange for the Order helping Vytautas in his struggle with Jogaila, Vytautas was to participate in helping the Order by providing services and helping against its (pagan) enemies (quibus concessis predictus dux una cum heredibus et successoribus suis tenetur ad nos servicia et auxilia prestanda contra omnes perturbatores Christiane religionis et hostes ordinis nostri). ${ }^{9}$ Moreover, a large body of the letters and correspondence, in addition to secular chroniclers and chroniclers associated with the Teutonic Order, framed the conquest of Žemaitija as a continuation of the Order's raison d'être, namely the war against non-Christians and enemies of the Church.

This paper seeks to address something more nuanced, and, to my knowledge, still under-explored. It will focus on the persistence of the Teutonic Order's self-image in the late 14th and early 15th century as expressed in the Order's correspondence and appeals to Christendom, and will address the communication and reception of this image and language, namely through a consideration of the role played by visual culture (particularly statues and frescoes in the Order's churches). While mostly a war of words and diplomacy, it is quite possible to link the messages expressed in these texts to a visual communication of the Order's self-image and inner perception of itself as a religious institution right before the beginning of its decline.

\section{Crusading imagery in the 14th century}

In order to understand the ideology of holy war and crusading as they were present in the campaigns to Žemaitija, we must first begin with a brief overview of the developments of these ideas throughout Christendom in the 14th century. The efforts to recover the Holy Land at this time were largely limited to planning and attempts

PETRAUSKAS, Rimvydas. Litauen und der Deutsche Orden: vom Feind zum Verbündeten. In Tannenberg - Grunwald - Žalgiris 1410: Krieg und Frieden im späten Mittelalter (Deutsches Historisches Institut Warschau. Quellen und Studien, Bd. 26). Hrsg. von Werner PARAVICINI, Rimvydas PETRAUSKAS, Grischa VERCAMER. Wiesbaden, 2012, S. 237-252.

9 CEVMDL, p. 5-6, No 15: 'Quibus concessis predictus dux una cum heredibus et successoribus suis tenetur ad nos servicia et auxilia prestanda contra omnes perturbatores Christiane religionis et hostes ordinis nostri.' 
to muster military forces, fostering political alliances between the rulers of Christendom, garnering financial support for crusades, and outlining religious justifications for doing so. As such, this period was known as the age of recovery planning. ${ }^{10}$ One notable exception to this is the expedition of Peter I of Cyprus in 1365, which managed to attack Alexandria. ${ }^{11}$

On the Baltic shore, the reality was much different. Seasonal expeditions were taking place virtually every year. Having conquered the Prussians in 1283, by the early 14 th century the Teutonic Order was in a full-fledged war against its new enemies: the Lithuanians. Peter von Dusburg, a priest in the Order and chronicler, recorded how peregrini de Alemania inspirante domino returned to Prussia again (iterum) to fight the Lithuanians in 1304, indicating his perception (and that of members in the Order) that the crusade continued. ${ }^{12}$ For nearly a century onwards, the Order would wage a series of annual campaigns against them which attracted the European nobility from as far afield as Italy, England and Spain, while steadily recruiting participants from the Holy Roman Empire, France and the Low Countries. As demonstrated in the foundational work on these campaigns, the so-called Reisen or Preussenreisen, Werner Paravicini has highlighted that they involved a complex blend of crusading ideals and chivalric virtues that formed the experience of the crusaders who journeyed to the Ordensland to fight the enemies of the Christian faith in the service of the Virgin Mary. ${ }^{13}$ One only need to consult the figures of John I the Blind, King of Bohemia, who 'in honour of Our Lady, vowed to journey to Prussia' in 1329, Louis of Hungary in 1356, Leutolten of Stadekk in 1361, or the famous Reise of Albert II, Duke of Austria, in 1377, all of whom were commemorated in heraldic poems highlighting the complex blend of service to the Virgin Mary and the Christian faith with the chivalric imagery popular in secular literature. ${ }^{14}$ As we see below, this imagery transferred

10 HOUSLEY, Norman. Contesting the Crusades. Oxford, 2006, pp. 122-124; BONTEA, Cornel. Comment Reconquérir la Terre Sainte? L'Exemple du Memoria et Via at Terram Sanctam. Medieval and Early Modern Studies for Central and Eastern Europe, 2016, vol. 8, p. 124.

11 HOUSLEY, N. Op. cit., pp. 126-127, outlines the interpretations of Peter's expedition in 1365.

12 PETER von Dusburg. Chronica terre Prussie. In Scriptores rerum Prussicarum. Die Geschichtsquellen der Preussischen Vorzeit bis zum Untergange der Ordensherrschaft (hereafter, SRP). Bd. 1. Hrsg. von Theodor HIRSCH, Max TÖPPEN, Ernst STREHLKE. Leipzig, 1861, S. 170. Also see PARAVICINI, Werner. Die Preußenreisen des europäischen Adels. Teil 1 (Beihefte der Francia, Bd. 17/1). Sigmaringen, 1989, S. 22-23; EHLERS, Axel. The Crusade of the Teutonic Knights against Lithuania Reconsidered. In Crusade and Conversion on the Baltic Frontier, 1150-1500. Ed. by Alan V. MURRAY. Farnham, 2001, p. 30; EHLERS, Axel. Die Ablaßpraxis des Deutschen Ordens im Mittelalter (Quellen und Studien zur Geschichte des Deutschen Ordens, Bd. 64). Marburg, 2007, S. 52-53. For critiques of participants on the Reisen as crusaders, see MASCHKE, Erich. Burgund und der preußische Ordensstaat. Ein Beitrag zur Einheit der ritterlichen Kultur Europas im Spätmittelalter. In MASCHKE, Erich. Domus Hospitalis Theutonicorum. Europäische Verbindungslinien der Deutschordensgeschichte. Gesammelte Aufsätze aus den Jahren 1931-1963 (Quellen und Studien zur Geschichte des Deutschen Ordens, Bd. 10). Bonn, 1970, S. 24; URBAN, William. The Teutonic Knights and Baltic Chivalry. The Historian, 1994, vol. 56, no. 3, pp. 524-526.

13 PARAVICINI, W. Die Preußenreisen..., Teil. 1, S. 23-25.

14 Kurze Preussische Annalen. 1190-1337. In SRP. Bd. 3. Leipzig, 1866, S. 3: 'Do der Bemische konigk in unser liben frawen ere eyne vart zu Littawen gelobde.' For Louis of Hungary, see HERMANN von Wartberge. 
over to the struggle for Žemaitija in the 15th century in both the written word and in the visual culture of the Ordensland.

The concept of fighting those enemies and, in some rare cases, the granting of indulgences for doing so (hallmarks of the crusade phenomenon) highlight that some aspects of crusading in the Holy Land had survived on the northeastern frontier of Christendom beyond the 13th century. ${ }^{15}$ Reisen organised by the Teutonic Order continued to draw participants throughout the 14th century, with nearly 300 separate expeditions occurring from 1305 to $1413 .{ }^{16}$ To cement the contemporary understandings of these wars, popular terms associated with crusading continued to be employed in chronicles and charters from the 1330 s to the 1390s. These included 'the way of the pilgrims' (via peregrinorum), ${ }^{17}$ 'sacred pilgrimage' (peregrinatio sancta), ${ }^{18}$ and 'pilgrimage' (peregrinatio), ${ }^{19}$ as well as the designation of some participants in these campaigns as 'pilgrims' (peregrini). ${ }^{20}$ William IV of Jülich-Gelders is a strong example. He journeyed to Prussia eight times, and also participated in the campaigns to Žemaitija in the late 14 th century. ${ }^{21}$ A letter of the Bishop of Pomesania, Johannes, refers to William as a pilgrim (peregrinus), and his expedition to Prussia as done 'to aid the land of Prussia and in defence of Christendom' (in subsidium terre Prussie et defensione christianitatis). ${ }^{22}$ Later, in 1390, Henry of Derby went to Prussia on crusade, where 'he was at war with the enemies of Christ, so that from

Chronicon Livoniae. Beilage V: Aus Peter Suchenwirt, Heinrich dem Teichner und anderen deutschen Dichtern. In SRP. Bd. 2. Leipzig, 1863, S. 159: 'In Preuzzenland mit wernder tât / lie sich der edel schauen / ze dînest unser vrauen / mit chunig, mit graven hôchgeporn / Vreien, dinstman auzerchorn, I mit ritter, cnechten mutes reich.'; For Leutolten, see Ibid.: 'Gên Preuzzen durch des gelauben êr / [...] / in der Littaue lande; I man slûc, man vie, man prande / durch Mariam die vil hêren / und den gelauben mêren / der hochgeteuerten christenhait.'; For Albert II of Austria, see Ibid., S. 161-173, here S. 161: 'Durich Preuzzenlant der fürste zogt / mit grôzer ritterschefte / [...] / Got und der magt zu êren.' Emphasis mine.

15 This was often done at the request of individual crusaders, and indulgences were likewise issued by the Teutonic Order itself. See EHLERS, A. The Crusade of the Teutonic Knights..., pp. 31, 35-36; EHLERS, A. Ablaßpraxis..., S. 63-64.

16 PARAVICINI, W. Die Preußenreisen..., Teil 2. Sigmaringen, 1995, S. 20-41.

17 For example, Tabulae Ordinis Theutonici: ex tabularii regii Berolinensis codice potissimum. Ed. Ernestus STREHLKE. Berolini, 1869, p. 204, No 212, a peace treaty from 26 November 1338, which refers to 'via peregrinacionis contra Lythwanos'.

18 Die Chronik Wigands von Marburg. Beilage IX: Englische Berichte. In SRP, Bd. 2, S. 794: 'Videns igitur dictus Henricus sibi periculum imminere, litem temporalem in peregrinantionem sanctam vertit.' Emphasis mine.

19 Ibid., S. 792: 'apud Danski tempore peregrinationis [emphasis GL] sue de absolutioni sibi concessa a papa nostro Bonifacio.' Also see GUARD, Timothy. Chivalry, Kingship and Crusade. The English Experience in the Fourteenth Century. Woodbridge, 2013, pp. 72-98, for English crusaders in the Baltic.

20 For example, see WIGAND von Marburg. Chronik. In SRP, Bd. 2, S. 651, 653, 655, 656, 661. Also see CDP, Bd. 4, S. 41, Nr. 34, which refers to 'christi pauperes et peregrini [...] servant necnon contra perfidos litwanos dicte fidei hostes ferventer exponebant prout exponent' in 1386; S. 56, Nr. 46: 'sanguinis effusione promotum in dispendium fidei orthodoxe, peregrini cum suis comitivis Lyvonie et Prussie partes devocionis ac indulgenciarum causa visitare volentes' in 1387.

21 For example, see WIGAND von Marburg. Op. cit., S. 649, which refers to Gelders' banner in 1393. Also see PARAVICINI, W. Die Preußenreisen..., Teil 1, S. 50, 60-66, for the analysis of the Prussian expeditions of William.

22 CDP, Bd. 4, S. 80, Nr. 59. 
this time onward nothing satisfied him more in spirit than to vindicate the disgrace to the crucified.' ${ }^{23}$ These examples were surely responses to the image projected by the Teutonic Order in its correspondence until the end of the 14th century, particularly evident in the letters and appeals of Hochmeister Konrad von Jungingen (d. 1408) to the rulers of Christendom, which will be discussed at greater length below. It was also an imagery present in local Prussian chronicles. For example, Johannes von Posilge, an official of the bishop of Pomesania in the late 14th century, referred to the wars of the Order against Lithuania with terms that continued to emphasise their sacral nature. Throughout the text, he refers to the brothers of the Order and its guests (i.e. crusaders) as fighting 'with the help of Our Lord' (mit der hulfe unsers herren). His accounts of the Siege of Kaunas in April 1362, the battle at Rudau in 1370, and the expedition of King Henry IV of England in 1390 serve as relevant examples of how Johannes perceived and reflected on the Order's campaigns as holy wars. ${ }^{24}$ Moreover, the inclusion of miracles while on campaign, such as his account of a Reise in 1394, further demonstrates his perception of the campaigns as holy causes and done with God's support and approval. ${ }^{25}$

While language and ideology centred on the campaigns against the unbelievers and the enemies of Christ as holy causes, reality was much different. The conversion of Jogaila to Christianity in August of 1386 brought a real crisis to the ideological programme of the Teutonic Order, namely in that with this event its raison d'être ceased to exist. Referred to in German historiography as the Heidenkampf (the struggle of the Order against pagans), this was central to the corporate identity of and worldview within the Order, forming a framework for virtually all of the Order's literary and historical canon, and, as this paper also highlights, its visual culture in Prussia. ${ }^{26}$

23 Die Chronik Wigands von Marburg. Beilage IX: Englische Berichte..., S. 795: 'In quo conflictu egregius adolescens Henricus cum inimicis crucis Christi confligebat, ut amodo nihil majus sibi in animo firmaret quam opprobrium vendicare crucifixi.'

24 For example, see ANNALISTA Thorunensis vs DETMAR von Lübeck vs JOHANN von Posilge. Chronik. In SRP. Bd. 3. Leipzig 1866, S. 82, 90-91, 167, 196, 200.

25 Ibid., S. 194-195.

26 WEISE, Erich. Der Heidenkampf des Deutschen Ordens. Erster Teil. Zeitschrift für Ostforschung, 1963, 12. Jhg., Hf. 3, S. 420-473; SARNOWSKY, Jürgen. Identität und Selbstgefühl der geistlichen Ritterorden. In Ständische und religiöse Identitäten in Mittelalter und frühen Neuzeit. Hrsg. von Stefan KWIATKOWSKI, Janusz MAtŁEK. Toruń, 1998, S. 112-118; THUMSER, Matthias. Ein neue Aufgabe im Heidenkampf? Pläne mit dem Deutschen Orden als Vorposten gegen die Türken. In Europa und die Türken in der Renaissance (Frühe Neuzeit, Bd. 54). Hrsg. von Bodo GUTHMÜLLER, Wilhelm KÜHLMANN. Tübingen, 2000, S. 139-176; CZAJA, Roman. Das Selbstverständnis der geistlichen Ritterorden im Mittelalter: Bilanz und Forschungsperspektive. In Selbstbild und Selbstverständnis der geistlichen Ritterorden (Ordines militares, vol. 13). Hrsg. von Roman CZAJA, Jürgen SARNOWSKY. Toruń, 2005, S. 9-10; KWIATKOWSKI, Krzysztof. Die „Eroberung Preußens" durch den Deutschen Orden - ihr Bild und ihre Wahrnehmung in der Literatur des Deutschen Ordens im 14. Jahrhundert. In Kryžiaus kary epocha Baltijos regiono tautu istorineje sqqmonejje. Sud. Rita Regina TRIMONIENĖ, Robertas JURGAITIS. Šiauliai, 2007, p. 142-154; KWIATKOWSKI, Krzysztof. Zakon niemiecki jako „corporatio militaris”. Część I: Korporacja i krag przynależących do niej. Kulturowe i społeczne podstawy działalności militarnej zakonu w Prusach (do poczq̨tku XV wieku). Toruń, 2012, s. 87, 95-109; WÜST, Marcus. Studien zum Selbstverständnis des Deutschen Ordens im Mittelalter (Quellen 
Following this conversion, the Order began to experience a significant decline in its support from the rulers of Christendom and the nobility as it continued to attempt to garner support for its campaigns to conquer Žemaitija. In 1388, Pope Urban VI, confirming the establishment of the diocese of Vilnius, praised Jogaila (now Władysław II Jagiełło) as a Christian king who threw aside idolatry and took holy baptism so that he would come to the true Christian faith. ${ }^{27}$ Further cementing the acceptance of Jogaila's conversion within western Christendom, expeditions led by the Order were prohibited. ${ }^{28}$ King Wenceslaus IV of Bohemia placed a ban on campaigning against the Lithuanians in 1394. According to Johannes von Posilge, Wenceslaus forbade the expeditions as a means to rally support for the struggles happening in his own kingdom, and accepted help from the King of Poland (with whom the Order was at war). ${ }^{29}$

Thus, the conversion of Jogaila and subsequent decline in support for the Order's campaigns sparked a series of polemical letters and an increased focus on language and rhetoric to legitimise future campaigns and garner international support. These were especially focused on depicting the King of Poland and Žemaitija as enemies of the Christian faith and dot the Order's correspondence to Christendom at the end of the 14th century. Konrad von Jungingen responded to Wenceslaus' decision by reminding the Emperor of the essential duty of his Order, and the years of support bestowed upon this institution by Emperors, Popes and Kings (including Wenceslaus' own predecessors, such as Ottokar II of Bohemia and John I of Bohemia). Therefore, he could not obey the order of the Emperor to not wage war against Poland and its allies. In his letter to Wenceslaus dated 15 August 1395, Konrad wrote that 'my Order was established to maintain the war against the unbelievers (ungeloubigen), and therefore my Order, by God's grace, has had the support of the Holy Roman Church, the Holy Roman Empire, and all Christian kings, princes and lords, to strike the land

und Studien zur Geschichte des Deutschen Ordens, Bd. 73). Weimar, 2013, S. 22-26, 39, 54-57. For recent analyses of the Order's depiction of this in its visual culture around the turn of the 15th century, see HERRMANN, Christofer. Der Hochmeisterpalast auf der Marienburg. Konzeption, Bau und Nutzung der modernsten europäische Fürstenresidenz um 1400 (Berliner Beiträge zur Bauforschung und Denkmalpflege, Bd. 17). Petersberg, 2019, S. 284-325, 498-522.

27 Kodeks dyplomatyczny katedry i diecezji wileńskiej. T. 1. Wyd. Jan FIJAŁEK, Władysław SEMKOWICZ. Kraków, 1932, s. 20-22, nr. 10: 'Sane nuper pro parte carissmi in Cristo filii nostri Wladislai regis [...] nobis fuit expositum, quod ipse rex, postquam favente domino nostro Ihesu Cristo, qui lux vera et candor est lucis eterne, sancti Spiritus gracia illustratus, abiecta ydolorum servitude et cecitatis errorum detracta caligne, ad agnicionem vere catholice et orthodoxe fidei pervenisset, sacro baptismatis fonte Renatus in quodom loco populoso Wilna nuncupato.' Emphasis mine.

28 HOUSLEY, N. Op. cit., pp. 132-133; BARONAS, Darius; ROWELL, S.C. The Conversion of Lithuania. From Pagan Barbarians to Late Medieval Christians. Vilnius, 2015, pp. 272-274.

29 ANNALISTA Thorunensis vs DETMAR von Lübeck vs JOHANN von Posilge. Chronik, S. 196-197: 'Item in design czitin was gros krig czwusschen dem Romischen konige czu Bemen und sinen lantherin [...] und schreibe deme meister und gebot, das her nicht sulde herrin dy lant czu Littowen und Russin.' For the decline in the relationship between Wenceslaus IV and the Teutonic Order, see RAUTENBERG, Wilhelm. Einwirkungen Böhmens auf die Geschicke des Ordenslandes Preußen im späten Mittelalter. Zeitschrift für Ostforschung, 1973, 22. Jhg., Hf. 4, S. 626-695, here S. 639. 
of the unbelievers. ${ }^{\prime 30}$ What resulted was a significant campaign based in the language of holy war and the image of the Teutonic Order as a defender of Christendom, a frequent theme in its diplomatic correspondence throughout the late 14th century regarding Poland. For example, Konrad wrote to the Procurator of the Teutonic Order in Rome in 1397 that he should remind the Pope of the cost and provisions that the Order took upon itself 'for the consolation of the whole of Christendom against paganism'. ${ }^{31}$ Moreover, in a letter to the princes of the Holy Roman Empire, Konrad reminded them of the Order's stance against the King of Poland, who, along with the Lithuanians and Russians, was 'an enemy of the holy cross of Christ'. ${ }^{32}$

\section{Žemaitija, daz ende der cristenheit, and holy war rhetoric in the 15th century}

The imagery and language of holy war in Prussia and the Baltic region lasted into the 15th century, and continued even after the defeat of the Teutonic Order at the Battle of Tannenberg (Grunwald) on 15 July 1410. As has been demonstrated in the work of Juhan Kreem and Madis Maasing, the idea of holy war persisted into the 16 th century, namely in the letters and charters documenting the campaigns of the Livonian Branch of the Teutonic Order against the Russians, though this is beyond the scope of the present article. ${ }^{33}$ In any case, there appears to have been a spiritual motivation for these campaigns, or at least the opportunity to act on them should a knight wish to do so. Now housed at the University of Pennsylvania, Oversize Ms. Codex 1087, a 15th-century copy of the Order's Rule, contains the so-called aplass von der reyse, an indulgence granted by the Order to those 'who come here [to Prussia - G.L.] with true intentions and uprightness and from their own cost to fight

30 CDP. Bd. 6. Königsberg, 1861, S. 10-11, Nr. 11: 'Ouch allirgned. herre, die sache die Ir myr anmutende seit von mines Ordins wegen Ich alleyne das nicht macht habe czu thun, want sie ist eyne grose sachte und die groste, worumb myn Ordin gestiftet ist czu halden den krig wedir die ungeloubigen, und dorumb myn Ordin von den gnaden gotis vorderunge hat gehat bis dese czeit und noch hat von der heiligen Romischen kirchen, von dem heiligen Reyche und von allen cristenlichen konigen, fursten und herren, die dy sache also wol angeet als mynen Orden, Besundern der herren, der land an die ungeloubigen stossen.'

31 CDP. Bd. 5. Königsberg, 1857, S. 117, Nr. 92: '[...] Wil unsir heilger vater uns nicht getruwen der koste und czerunge die wir tragen czu troste der gantzen heilgen cristenheit wider die heidenschaft, her dirfare sich von den die is wissen, und gloyben wol her lase uns von uswenyger czerunge unbeswert, als ferre als ym liebit das czunemen der heilgen cristenheit.' Emphasis mine.

32 Ibid., S. 125, Nr. 99: 'Zcum irsten das undir den Polan, Littowen und Russen als grose gemeinschaft ist, das sy offenbar sprechen was Littowen und Russen angehet, das geht ouch an das Rich zu Polan, wenn si wellen ungescheiden syn von enander, dy io noch echter und vynde synt des heilgen Cruces cristi, und von In dy gesessenen Cristengloybigen grose vor mussen liden.'Emphasis mine.

33 KREEM, Juhan. Crusading Traditions and Chivalric Ideals: The Mentality of the Teutonic Order in Livonia at the Beginning of the Sixteenth Century. Crusades, 2003, vol. 12, pp. 233-250; MAASING, Madis. Infidel Turks and Schismatic Russians in Late Medieval Livonia. In Fear and Loathing in the North: Jews and Muslims in Medieval Scandinavia and the Baltic Region. Ed. by Cordelia HESS, Jonathan ADAMS. Berlin, Boston, 2015, p. 363. 
with the pagans' (zu fechten mit der heidenschafft)'. ${ }^{34}$ Therefore, the institutions and framework of the crusade survived in 15th-century Prussia, but specific elements were highlighted that deserve analysis in the present section.

Examples of rhetoric concerning holy war with respect to Prussia in the 15th century can be seen not only in the sources associated with the Teutonic Order. They also appear in the accounts of the Order's 'guests', particularly those from France, Burgundy and the Holy Roman Empire. ${ }^{35}$ These texts often employ language associated with the Holy Land crusades, perhaps most notable being the use of the term 'Saracen' to refer to the people of Lithuania and Žemaitija. As demonstrated in the work of Alan V. Murray and Loïc Chollet, the use of this term (Saracen) was particularly in vogue among European soldiers journeying to the Baltic to support the Teutonic Order. It functioned to frame those conflicts as holy causes, while also placing the enemies within the framework of the Other following the conversion of Lithuania in $1386 .{ }^{36}$ This imagery and literary development lasted throughout the end of the conversionoriented expeditions to the Baltic, exemplified by Flemish knight and ambassador of the Duke of Burgundy, Guillibert de Lannoy, who wrote in his account of his travels to the north in 1412-1413. In this travelogue, he writes that he journeyed to Prussia 'to fight against the unbelievers' (pour aler en Prusse contre les mescreans), and he refers to the false religion of the King of Poland, Władisław II Jagiełło, and the Duke of Pomerania, Wratislaw VIII, qui favorisoient les Sarrasins. ${ }^{37}$

The majority of the imagery surrounding holy war in Žemaitija comes, not surprisingly, from the correspondence of the Teutonic Order. This is especially the case for the correspondence of Grand Master Konrad von Jungingen and his successors. There are specific themes in the language of these letters that reflect the continuation of holy war, as opposed to a more distinct element of language associated with crusading. This falls more in line with the interpretation of holy war proposed by Carl Erdmann: war against pagans was a distinct, just cause, and meritorious, though it was

${ }_{34}$ Oversize Ms. Codex 1087, [15th century]. University of Pennsylvania, Kislak Center for Special Collections, Rare Books and Manuscripts, fol. 22r-22v: 'Ditz ist ablas des deutzschen orden bestetiget von dreyen bebsten [...] Disen vor beschriben gnade die findet man zu preussen und zu liffland alle die jenen die do hin komen mit warer [rew] und ganz pricht und uff ire eygene kost zu fechten mit der heidenschafft, und es ist bestetiget in dem gemainen concilio.' I am thankful to Dr John Pollack, Curator at the Kislack Center for Special Collections, Rare Books and Manuscripts, for directing me to the digitised version of this text. URL: <https://openn.library.upenn.edu/Data/0002/html/mscodex1087.html>.

35 CHOLLET, Loïc. Les Sarrasins du Nord. Une histoire de la croisade balte par la littérature (XIIe - XVe siècles). Neuchâtel, 2019.

36 MURRAY, Alan V. The Saracens of the Baltic: Pagan and Christian Lithuanians in the Perception of English and French Crusaders to Late Medieval Prussia. Journal of Baltic Studies, 2010, vol. 41, no. 4, pp. 413429; CHOLLET, L. Les Sarrasins du Nord..., p. 149-153.

37 ANNALISTA Thorunensis vs DETMAR von Lübeck vs JOHANN von Posilge. Chronik. Beilage V: Aus niederländischen Quellen. In SRP, Bd. 3, S. 443-452, here S. 444-445. 
not the same as a crusade. ${ }^{38} \mathrm{~A}$ letter, written by the Grand Master to the Holy Roman Emperor, Wenceslaus IV, depicts the expedition as service to the Church and the Virgin Mary, while also spreading the Christian faith (gote unserm herren und synir werden mutter czu lobe und czu eren, und merunge des heiligen cristiglouben). Here, we have a specific continuity of the conversion-oriented crusade imagery after $1386 .{ }^{39}$ In this case, the struggle for Žemaitija is reflected as labour done in the name of Christianity and the Virgin Mary, popular themes in the crusading rhetoric of the Teutonic Order and the participants in the Reisen.

The defence of Christendom emerged as a common theme in garnering support and legitimisation for the campaigns in Žemaitija into the 15th century, and formerly pagan rulers could still do honour to Christendom through their alliances with the Order. In 1405, for example, Konrad von Jungingen wrote to Vytautas, commending him on building two castles in Žemaitija to help begin the conversion process there. Not only did Vytautas help the Order, he also 'honoured and served the whole of Christendom' (nicht alleine unserm orden czu hulffe und czu fromen, sunder der ganczen cristenheit czu eren und czu dinste). ${ }^{40}$ That same year, he appealed to the Pope concerning his ban on future campaigns against the Lithuanians, emphasising this imagery while also citing phrases that can also be found in the Chronicon terre Prussie of Peter von Dusburg. The Teutonic Order is described as fighting 'for the expanse of the vineyard of the Lord Sabaoth' (ad dilatandam vineam domini Sabaotha), the protectors of the Litter of Solomon and therefore of the Church of Christ, 'fighting the Lord's war against the resistance of the infidels and the tyranny of the schismatics for the past century'. ${ }^{41}$ Four years later, in 1409, when Vytautas had allied with the Poles and the Žemaitijan uprisings had begun, Grand Master Ulrich von Jungingen emphasised to the princes of Christendom, 'whom God had assembled', that this betrayal on the part of Vytautas was done against God, the Order, and the whole of Christianity. ${ }^{42}$ Later, in May 1410, Ulrich again asked for the support of the princes of the Holy Roman Empire to journey to Prussia for the honour of knighthood and of

38 For example, see ERDMANN. Carl. The Origin of the Idea of Crusade. Princeton, 1977, pp. 95-108, for an analysis of wars against pagans on the eastern German frontier.

39 CDP, Bd. 6, S. 98-99, Nr. 96.

40 CEVMDL, p. 117-118, No 234: 'Sunderlich grosmechtiger herre, got der almechtige geruche ewer beloner czu sein vor die buwunge des huses, in der ir euch swerer arbeit der ewern so gar willeclich habe dirczeiget, nicht alleine unserm orden czu hulffe und czu fromen, sunder der ganczen cristenheit czu eren und czu dinste, und dirkennen io dorus guete und gnade, die ir czu unserm orden target.' Emphasis mine.

${ }^{41}$ CDP, Bd. 6, S. 188-189, Nr. 137: 'Verum cum predecessores mei et ego cum toto Ordine meo semper eramus sicud et sumus filii obediencie. nec umquam pretergressi sumus studio yotam Mandata apostolici. Quinvero super erogantes nos et nostra ad dilitandam vineam domini Sabaotha et ad strenue gubernandum Salomonis lectulumb christi videlicet Ecclesie indefesse prelia domini contra occursus infidelium et Scismaticorum tyranidem a centum annis supra et citra sine interpolacione seu interrupcione gessimus bona fide.'

42 CEVMDL, p. 181, No 409: 'Ir herren ritter und knechte, als euch got her gesammelt hat, wir bitten euch alle, als die, den got und ere und die cristenheit libet, das ir unszern gnedigen herren konig bitten weldet, das her dem vorretnissz das alzo wider got, den orden und die cristenheit ist gescheen.' Emphasis mine. 
Christianity, thus appealing to the multi-faceted nature of holy war in the medieval Baltic and continuing the elements from the Order's famous Reisen. ${ }^{43}$ A particularly demonstrative example of this element of religious warfare in 15th-century Prussia can be seen in a letter from Heinrich von Plauen to the princes and lords of Germany in October 1412, delivered by the Commander of Thorn, Eberhard von Wallenfels. ${ }^{44}$ The letter is a response to complaints waged by the Kingdom of Poland and Vytautas against the Order, and makes it clear that to trust these words is to do harm to the whole of Christianity (der ganzen cristenheit). It refers to Žemaitija, too, as the Order's enemies (unser vinde die Samaythen), while grouping them with all of the heathen nations, namely the Lithuanians, Tartars and Russians, 'and many other unbelievers, pagans and enemies of the cross of Christ'. ${ }^{45}$ In these examples, the language of the Heidenkampf clearly survived in the diplomatic material of the Teutonic Order, but it had experienced a necessary change to account for the Christian status of the Kingdom of Poland and Vytautas of Lithuania. Highlighting that they were not true Christians, but actually harmers of Christianity, the Order attempted to legitimise its struggles and to gain support in a time of considerable crisis.

Recent studies on the crusades from the perspective of social and cultural history have demonstrated convincingly that memory and commemoration were critical elements of the crusade experience. This can be seen in the works of Jessalynn Bird, Megan Cassidy-Welch, and Stephen Spencer with particular focus on crusading and its impact on memory, within the Holy Land and beyond. ${ }^{46}$ With respect to the north-

43 Ibid., p. 207, No 440: 'Worumb allirdurchluchster forste grosmechtiger konig und liber gnedier herre, ich euwir koniglich hochwirdikeit mit andachtigen beten flisiclichen bitte [...] zemlich vorterpnisse an minen orden und ersten an der cristenheit czu herczen nemet, und wellet gunnen euwir hochwirdikeit, heren, forsten, rittern und knechten mines ordens lande czu besuchin, welche die do gnade haben lutterlich durch got, und ritterschaft und czu beschirmunge der heiligen cristenheit, dorumb ich mit minen ganczen orden den almechtigen got vor euwir gelukseligkeit czunemen und lang leben andachtichlicn bitten wil.'

44 VOIGT, Johannes. Namen-Codex der Deutschen Ordens-Beamten, Hochmeister, Landmeister, Großgebietiger, Komthure, Vögte, Pfleger, Hochmeister-Kompane, Kreuzfahrer und Söldner-Hauptleute in Preussen. Königsberg, 1843, S. 57; VOIGT, Johannes. Geschichte Preussens, von den ältesten Zeiten bis zum Untergange der Herrschaft des Deutschen Ordens. Bd. 7: Die Zeit vom Hochmeister Ulrich von Jungingen 1407 bis zum Tode des Hochmeisters Paul von Rußdorf 1441. Königsberg, 1836, S. 173-174.

45 CEVMDL, p. 233-236, No 498, here p. 235-236: 'Ir lieben ritter, knechte, stete und alle die alhie besammelt sien, das horet ir alle wol! Bu irkenne wir, das wir deschen schaden des lands Samaythen haben vom herrn koninge czu Poland und sime antragen und von nimand andirs [...] mit alle siner macht der Polner und soldener, doczu im qwam der herczog Wytoud mit Littauwen, Samayten, Tattern, Bessermenien, Russen und ander vil ungloubiger geczungen der heiden und finden des cruces Cristi, und czogen mit gewalt ungewarneter dinge kegen des ordens landen.'

46 For example, BIRD, Jessalynn. Preaching and Crusade Memory. In Remembering the Crusades and Crusading. Ed. by Megan CASSIDY-WELCH. London, New York, 2017, pp. 13-33; CASSIDY-WELCH, Megan. Before trauma: the crusades, medieval memory and violence. Continuum. Journal of Media \& Cultural Studies, 2017, vol. 31, no. 5, pp. 619-627; CASSIDY-WELCH, Megan. The Stones of Damietta: Remembering the Fifth Crusade. In Papacy, Crusade, and Christian-Muslim Relations. Ed. by Jessalynn BIRD. Amsterdam, 2018, pp. 195-210; SPENCER, Stephen J. Feelings of betrayal and echoes of the First Crusade in Odo of Deuil's De profectione Ludovici VII in Orientem. Historical Research, 2019, vol. 92, no. 258, pp. 657-679. 
ern frontiers of the crusading movement, the works of Gustavs Strenga and Kurt Villads-Jensen have begun to consider the role of memory in portraying the religious nature of the crusades of the Teutonic Order, particularly in the region of Livonia, during the 13 th century. ${ }^{47}$ Memory and commemoration were likewise important for the development of holy war and the perception of the campaigns in Žemaitija as holy causes. This is demonstrated in the many calls for potential supporters of the Order to remember their ancestors and to remember the Order's prestigious campaigns of earlier days, taking them to heart (zcum hertzen nemen). This general call to remember could also include more specific examples, employing Biblical imagery. In this instance, we see how memory and the act of remembering were used to prepare for warfare amongst brethren in the Order and within the Ordensland. ${ }^{48}$ The visual manifestations of this phenomenon will be discussed in the coming section of this paper.

An interesting trope that emerges sometimes in the written correspondence was to portray Žemaitija as the end of the Christian world (daz ende der Cristenheit). This terminology was employed in the Teutonic Order's correspondence quite early on, one of the first examples being a letter of 1401 describing the end of a peace treaty between Vytautas and the Order, in which the Order and its knights are referred to as settling 'on the end of Christendom, standing against paganism'. ${ }^{49}$ It was also used in a letter from Grand Master Heinrich von Plauen to the princes of Christendom in May 1411. In this example, he scolds the princes for neglecting the Order, who stood strongly against paganism 'on this end of Christendom' (in creftelichen wederstanden werden an deszem ende der cristenheit), proclaiming that Vytautas had hosted embassies from the Tatars and the Turks, bringing great harm to the poor land of the Order. ${ }^{50}$ This frames the conflicts in Žemaitija alongside the development of bulwark

47 VILLADS JENSEN, Kurt. Physical extermination of physical sin - Remarks on theology and mission in the Baltic region around 1200. In Sacred Space in the State of the Teutonic Order in Prussia (Publikacji Centrum Mediewistycznego Wydziału Nauk Historycznych UMK, nr. V; Sacra Bella Septentrionalia, t. II). Ed. by Jarosław WENTA, Magdalena KOPCZYŃSKA. Toruń, 2013, pp. 87-99; STRENGA, Gustavs. Remembering the Common Past: Livonia as a lieu de mémoire of the Teutonic Order in the Empire. In Livland - eine Region am Ende der Welt? Forschungen zum Verhältnis zwischen Zentrum und Peripherie im späten Mittelalter (Quellen und Studien zur baltischen Geschichte, Bd. 27). Hrsg. von Anti SELART, Matthias THUMSER. Köln, Weimar, Wien, 2017, S. 347-370.

48 This is the subject of a publication in preparation by Krzysztof Kwiatkowski and the author.

49 CDP, Bd. 6, S. 113-117, Nr. 112, here S. 116: 'Sunder unser homeister und syne gebitiger sampt mit unserm gantzen Orden, den euwir gosmechtige gnade und andere Cristene forsten, unsere gnedigen herren an das ende der Cristendheit gesatzt haben, der heidenschaft wedir tzstende.'

50 CEVMDL, p. 223-224, No 477: 'Wir thun ouch euwir herlichkeit czu wissen, das der egenante herre koning und herczog Wytout in Littowen bie enander sien, und czu in sint gekomen des von Thatern und Torken achtbare boten handeln, wir sunder czwifel und nicht gutes vorsehn, und do got vor sie, wie wir noch eins und unser armes land obirfallen wurden mit semelicher heidenischer und uncristlicher undith, is were czu besorgen das is an euch, an andere heren und forsten lute und land, die in gelegen weren ouch komen mochte, is were denne in creftliclichen wederstanden werden an deszem ende der cristenheit, das wir mit nichte mogen gethun ane hulfe und entzetczunge euwir und ander cristenlicher heren und forste, die wir umb ein solchs, ap is not geschege anruffen und anlangen musten.' 
rhetoric popular at the turn of the 15th century, namely the use and propagation of the antemurale christianitatis rhetoric. This construct was used throughout the 14 th to 16 th centuries to manifest the political, cultural and social identities of individual kingdoms, including the Grand Duchy of Poland-Lithuania. As outlined in the extensive work of Paul Srodecki, this was key in the early formation not only of national identities, but of Christian ones in the later Middle Ages, providing an insight into collective identities and images. ${ }^{51}$ In this sense, we can place the conquest of Žemaitija into a spatial narrative, reflective of the mental orientation of the Teutonic Order and its supporters regarding the conquest of this last frontier and the expansion of Christianity. The Order's chroniclers of the 14th century, especially Peter von Dusburg and Nicolaus von Jeroschin, created a geography in Prussia centred on the miraculous and heroic acts of knights and crusaders from the 13th-century conquests. ${ }^{52}$ Moreover, the protection of the land and the expansion of the Christian faith over the enemies of God were embedded into the Order's liturgy and statutes, thus linking the sacralisation of said land with the spiritual identity of the Order and with the rituals performed on and off the battlefield..$^{53}$ In this sense, the term ende der Cristenheit becomes a topos associated with the Teutonic Order's campaigns in Žemaitija following the conversion of Lithuania in 1386 and its entire mission to fight the enemies of God and of the Church. While this did not ultimately lead to concrete expeditions or efforts from the rulers of Christendom following the defeat of the Order at Tannenberg, the language and imagery demonstrates the importance of the campaigns in Žemaitija within the Teutonic Order's self-image and ideological projection to its external supporters during the early decades of the 15th century.

51 SRODECKI, Paul. «Murus et antemurale pollens et propugnaculum tocius christianitatis.» Der Traktatenstreit zwischen dem Deutschen Orden und dem Königreich Polen auf dem Konstanzer Konzil. Schweizerische Zeitschrift für Religions- und Kulturgeschichte, 2015, 109. Jhg., S. 47-67; SRODECKI, Paul. Schilt der Cristenheite i Scutum christianitatis - spory polsko-krzyżackie a retoryka przedmurza / tarczy na początku XV wieku. In Unia w Horodle na tle stosunków polsko-litewskich od Krewa do Zaręczenia wzajemnego Obojga Narodów. Red. Sławomir GÓRZYŃSKI. Warszawa, 2015, s. 147-163; SRODECKI, Paul. Antemurale-based frontier identities in East Central Europe and their ideological roots in medieval/early modern alterity and alienity discourses. In Collective Identity in the Context of Medieval Studies. Ed. by Michaela ANTONÍN MALANÍKOVÁ, Robert ANTONÍN. Ostrava, 2016, pp. 97-120; SRODECKI, Paul. Władysław III and the Polish-Hungarian Bulwark topoi against the Background of the Ottoman Threat in the 15th Century. In Hungaro-Polonica. Young Scholars on Medieval Polish-Hungarian Relations. Ed. by Dániel BAGI, Gábor BARABÁS, Zsolt MÁTÉ. Pécs, 2016, pp. 327-356.

52 VERCAMER, Grischa. Zeit in Peters von Dusburg Chronica terre Prussie (1326). Chronologische Ordnung oder Mittel zum Zweck? Zapiski Historyczne, 2011, t. 74, z. 4, s. 517-533, especially s. 525-532; LEIGHTON, Gregory. Did the Teutonic Order create a sacred landscape in thirteenth-century Prussia? Journal of Medieval History, 2018, vol. 44, no. 4, pp. 457-483.

53 Die Statuten des Deutschen Ordens. Hrsg. von Max PERLBACH. Halle, 1890, S. 132, Gebet 7: 'Bittet ouch vor alle die lant, die vor der heidenschaft legen, daz Got mit sîme rate unde craft zu hulfe kome, daz Gotes geloube unde minne dâ inne gebreitet werde, also daz sie allen iren vîenden mugen widerstên.' Emphasis mine. Also, KWIATKOWSKI, Krzysztof. Zakon niemiecki..., s. 88, notes the obligation to protect the Holy Land 'and other lands from God's enemies'. 
However, there was also a contrasting image that was brought against the knights at the Council of Constance, namely by the Poles and delegates from Žemaitija. ${ }^{54}$

\section{Linking the message of holy war against the Žemaitijans with the visual culture of Prussia}

The visual culture of the Teutonic Order in the later middle ages, particularly in the time of the Reisen, has been examined in the works of Werner Paravicini, who already in 1981 provided a commentary on the visual culture and its relationship to the Order's campaigns. ${ }^{55}$ Still, this serves as one of the best examples to study the relationship between the Order's rhetoric and the reception of this by its supporters, in addition to the local Christian population. ${ }^{56}$ This segment will outline the sites to be discussed, the use of these sites by participants on the Reisen, and the relationship of the language used in the Order's letters and appeals to Christendom to the scenes within the churches and chapels of the Order, particularly around Königsberg.

One of the most important public spaces in which the Order could reflect its ideology through visual media was the Great Refectory of its headquarters at Marienburg (Malbork), as well as the Knights Hall. Here, the Grand Master would host his guests, who ranged from messengers on behalf of kings from Europe, royal figures themselves (such as Princess Anna of Lithuania, in 1400), and guests who came to participate on the Reisen. For example, Guillibert de Lannoy visited the palace in 1413 and elaborated on its monumental appearance (est ville et chastel tres fort). ${ }^{57}$ The wall paintings and frescoes in the Knights Hall, the space in which guests and crusaders

54 CEVMDL, p. 1001-1018, Appendix VI, lists the complaints brought against the Teutonic Order at Constance. Also see CHOLLET, Loïc. Croisade ou évangélisation? La polémique contre les Chevaliers Teutoniques à l'aune des témoignages des voyageurs français de la fin du Moyen-Âge. Ordines Militares. ColIoquia Torunensia Historica, 2015, t. 20, p. 175-203; CHOLLET, Loïc. Von Friedenverträgen bis zum Konzil von Konstanz (1414-1418): Schemaiten und die rechtliche Stellung von heidnischen Völkern. In Od traktatu kaliskiego do pokoju oliwskiego. Polsko-krzyżacko-pruskie stosunki dyplomatyczne w latach 1343-1660 = Vom Frieden von Kalisch bis zum Frieden von Oliva. Diplomatische Beziehungen zwischen dem Königreich Polen und dem Deutschen Orden /Herzogtum Preußen in den Jahren 1343-1660. Red. Almut BUES, Janusz GRABOWSKI, Jacek KROCHMAL, Grischa VERCAMER, Hubert WAJS. Warszawa, 2014, s. 227-237; SARNOWSKY, Jürgen. The Military Orders and Crusading in the Fifteenth Century: Perception and Influence. In Reconfiguring the Fifteenth-Century Crusade. Ed. by Norman HOUSLEY. London, 2017, pp. 125-128, for an overview of the Order's reception in the 15th century.

55 PARAVICINI, W. Die Preußenreisen..., Teil 1, S. 305-309.

56 PARAVICINI, Werner. Verlorene Denkmäler europäischer Ritterschaft: Die heraldischen Malereien des 14. Jahrhunderts im Dom zu Königsberg. In Kunst und Geschichte im Ostseeraum: Tagungen 1988 und 1989 (Homburger Gespräche, Hf. 12). Hrsg. von Erich BÖCKLER. Kiel, 1990, S. 67-168.

57 ANNALISTA Thorunensis vs DETMAR von Lübeck vs JOHANN von Posilge. Chronik. Beilage V: Aus niederländischen Quellen. In SRP, Bd. 3, S. 444: 'Item: de Danzique m'en alay sur charioz devers le dit hault maistre, que je trouvay a Mariembourg, qui est ville et chastel tres fort, ou quel gist le trsor, la force et tout le trtrait de tous les seigneurs de Prusse.' Emphasis mine. 
were received by the Order throughout the 14th century, reflected the Marian ideology of the Teutonic Order. The only surviving example is an image of the Coronation of the Virgin. ${ }^{58}$

However, it should be remembered that Marienburg was not a main gathering point for participants on the Reisen and the expeditions to Žemaitija in the 14th and 15th century. Only a few examples of crusaders visiting here can be traced, such as Henry IV of England, in 1390.59 Instead, these figures flocked toward Königsberg and were hosted by the Great Marshal. The cathedral of Königsberg, dedicated to St Adalbert, St Catherine of Alexandria, and, of course, the Virgin Mary, presented a visual depiction of the nature of crusading and holy war on the Lithuanian frontier. ${ }^{60}$ This was specifically a series of frescoes in the choir of the cathedral depicting the Speculum Humanae Salvationis, an allegorical text linking the Old and New Testaments which was one of the most popular in Europe throughout the 14th century. In 1930, Walter Seydel analysed and catalogued the entire series of images in the cathedral, which represented the story visually. ${ }^{61}$ The same series of images could be seen on a smaller scale, at the small church in Arnau (Rodniki, Kaliningrad oblast) dedicated to St Catherine. Images of the Wise and Foolish Virgins, the Last Judgment, and the figures of David, Daniel, and Samuel adorned the walls of this church, which was visited by participants on the Reisen throughout the 14th and 15th century. In both churches there were also more secular depictions related to the crusades in Lithuania and, likely, Žemaitija, which were not directly part of the Speculum image programme. These were the depictions of coats of arms of participants on the Reisen. In Königsberg cathedral, there were also representations of knights themselves carrying banners. ${ }^{62}$ Such commissions were commonplace among crusaders to the Baltic, for example, William, Count of Ostrevant, who paid two marks for a table to be hung in Königsberg after his Reise in February of $1386 .{ }^{63}$

Other important resources for attempting to link the visual culture in the 15th century to the Order's ideological programme expressed in its correspondence with the rulers of Christendom come from local pilgrimage churches around Königsberg, the most important of them being a small church dedicated to the Virgin Mary at Juditten (Mendelevo, Kaliningrad oblast). This is the oldest stone church in the region,

58 EMERY, Anthony. Malbork Castle - Poland. The Castle Studies Group Journal, 2007-2008, no. 21, p. 146.

59 Rechnungen über Heinrich von Derby's Preussenfahrten 1390-91 und 1391. Hrsg. von Hans PRUTZ. Leipzig, 1893, S. 108: 'Et liberate domino per manus dicti Hugonis pro oblacionibus suis ad sanctam Annam, 3 s. 4 d. st. Et dati Rogero Hous et Johanni Gray ad sanctam Annam de elemosinis domini ibidem, 6 s. 8 d. st.' For Henry's Reisen, also see PARAVICINI, W. Die Preußenreisen..., Teil 1, S. 115-135, especially S. 134.

60 The cathedral was founded on 11 January 1302. See Urkundenbuch des Bisthums Samland. Hf. 1. Hrsg. von Carl Peter WOELKY, Hans MENDTHAL. Leipzig, 1891, S. 108-110, Nr. 200.

61 SEYDEL, Walter. Mittelalterliche Wandmalereien im Chor des Domes zu Königsberg Pr. Königsberg, 1930.

62 PARAVICINI, W. Verlorene Denkmäler..., S. 73-75.

63 Die Chronik Wigands von Marburg. Beilage IX: Niederländische Berichte. In SRP, Bd. 2, S. 768. 
dated to the end of the 13th century, and first mentioned in a document from $10 \mathrm{Au}$ gust 1287 issued by Konrad von Thierberg, Prussian Master from 1284 to $1287 .{ }^{64}$ The history of the church until the 14th century remains obscure, though at the time of Hochmeister Konrad Zöllner von Rotenstein (d. 1393) and Konrad von Jungingen, it had emerged as a significant pilgrimage shrine with a miraculous statue of the Virgin Mary. ${ }^{65}$ Throughout the late 14th and into the 15th century, there are records of crusaders and members of the Order making donations at the shrine in 1388-1389, during the Reise of William of Guelders, ${ }^{66}$ and in $1402 .{ }^{67}$ But what was the image programme in the small church? Photographs from 1948 reveal a considerable amount of information concerning the depiction of the Order's mission from a visual perspective and in apocalyptic terms. Knights in the Order are represented kneeling before the Virgin Mary, perhaps a link between the pilgrimage shrine itself, while also reflecting the ideological message expressed in the Order's appeals to the princes, knights, and rulers of Christendom. As pointed out above, crusading and holy war in the 15th century were linked to service of the Virgin Mary, and this becomes solidified in the visual culture of Prussia through the depictions in the church of Juditten.

The strongest link between the church, which became connected with warfare in the southern Baltic region due to its patronage by crusaders fighting the viende gotis, was a painting of the Virgin Mary with her arms opened, protecting a group of Teutonic Knights and what appear to be kings, along with churchmen. [Figure 1] The image was located on the main arch in the church, and faced westward, to those who are entering the church and approaching to the east. Here, we see a fascinating parallel to one of the most iconic artistic elements of the Ordensland in the 15th century: the so-called Schreinmadonna from Elbing (Elbląg, Poland). Painted some time around 1400, the shrine opens and inside can be seen a Teutonic Knight, kneeling in service to the Virgin Mary [Figure 2], along with kings and churchmen. ${ }^{68}$ These portable shrines were often part of the church furnishings in the Ordensland and in Europe, but they were also brought on campaign as portable shrines for holding

64 Preußisches Urkundenbuch. Politisches (allgemeine) Abteilung. Bd. I. 2. Hälfte. Hrsg. von August SERAPHIM. Königsberg, 1909, S. 322-325, Nr. 514.

65 STORCH, Ernst Ludwig. Die Kirche und das Kirchspiel Juditten im Landkreise Königsberg. Ein Beitrag zur vaterländischen, Kirchen- und Kultur-Geschichte Preußens. Königsberg, 1861, S. 1-13; PARAVICINI, W. Die Preußenreisen..., Bd. 1, S. 305.

66 WIGAND von Marburg. Op. cit., S. 635-636; Die ältere Hochmeisterchronik. In SRP, Bd. 3, S. 615.

67 Das Marienburger Tresslerbuch der Jahre 1399-1409. Hrsg. von Erich JOACHIM. Königsberg, 1896, S. 181: '2 scot of die toufel bey dem wege, als man reyt von Judynkirchin ken Koningisberg.' Emphasis mine.

68 One of the earliest studies is that of DIDRON, Édouard. Étude sur les images ouvrantes: et la vierge en ivoire du Louvre. Paris, 1870. For these figures as objects associated with the Teutonic Order, see FRIES, Walter. Die Schreinmadonna. Anzeiger des Germanischen Nationalmuseums. Jhg. 1928 und 1929. Nürnberg, 1929, S. 7-23; BAUMER, Christoph. Die Schreinmadonna. Marian Library Studies, 1978, vol. 9, art. 6, pp. 259-266; SCHLEIF, Corine. Die Schreinmadonna im Diözesanmuseum zu Limburg. Ein verfemtes Bildwerk des Mittelalters. Nassauische Annalen. Jahrbuch des Vereins für Nassauische Altertumskunde und Geschichtsforschung, 1984, vol. 95, S. 45-46. 


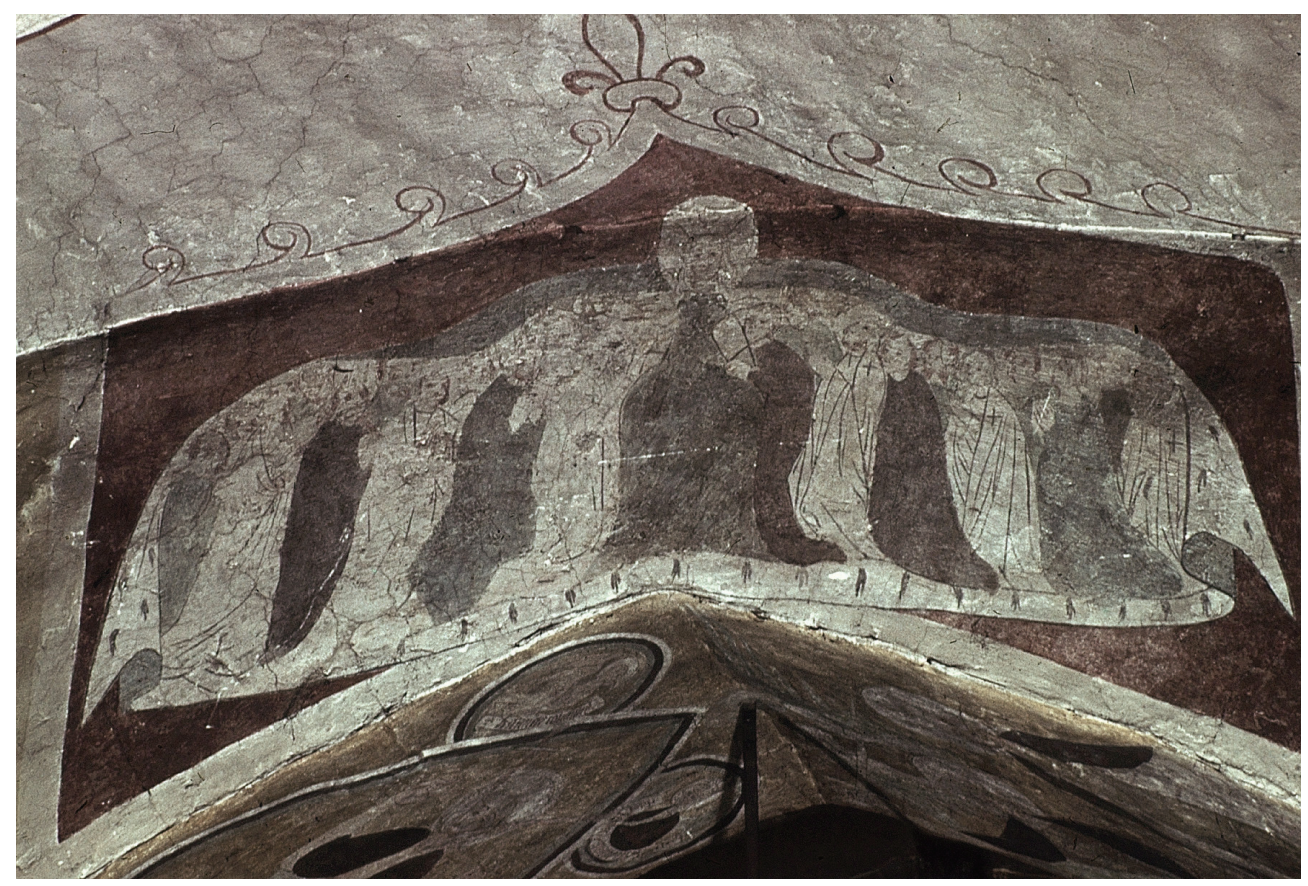

Figure 1. Fresco of the Virgin Mary as Protector. Juditten Church, Königsberg, c. 1390-1400. Image photographed c. 1940. Image Credit: Rudolf Schulze-Marburg, Zentralinstitut für Kunstgeschichte, Farbdiaarchiv

mass since at least 1344, when Hochmeister Ludolf König von Weizau (d. 1348) was granted permission by Pope Clement VI to carry 'portable altars' (altari portatili) on campaigns in laudem dei et virginis Marie contra paganos. ${ }^{69}$ These privileges were reissued on 11 October 1360, 28 September 1363, and in September $1368 .^{70}$ The parallel in the imagery of these sculptures unique to the Ordensland and the fresco at Juditten, then, would speak to the further association of the campaigns in Lithuania and Žemaitija as done in honour of the Virgin Mary, in support of the Teutonic Order, and benefitting Christendom, thus linking directly with the messages in the Order's polemical texts sent throughout Europe to garner support. Further examples can be seen to support this, such as an image of a Teutonic Knight kneeling before the Virgin. [Figure 3]

69 LEIGHTON, Gregory. Reysa in laudem Dei et virginis Marie contra paganos: The Experience of Crusading in Prussia during the Thirteenth and Fourteenth Centuries. Zeitschrift für Ostmitteleuropa-Forschung, 2020, 69. Jhg., Hf. 1, S. 1-25. For the Papal bulls, see CDP. Bd. 3. Königsberg, 1848, S. 71-72, Nr. 48.

70 Avignonesische Quellen zur Geschichte des Ordenslandes (1342-1366) (Beilage zum Jahresbericht des Königlichen Gymnasiums zu Braunsberg, Nr. 3). Hrsg. von Arthur MOTZKI. Braunsberg, 1914, S. 43, Nr. 84; S. 51, Nr. 109; CDP, Bd. 3, S. 126, Nr. 91. 

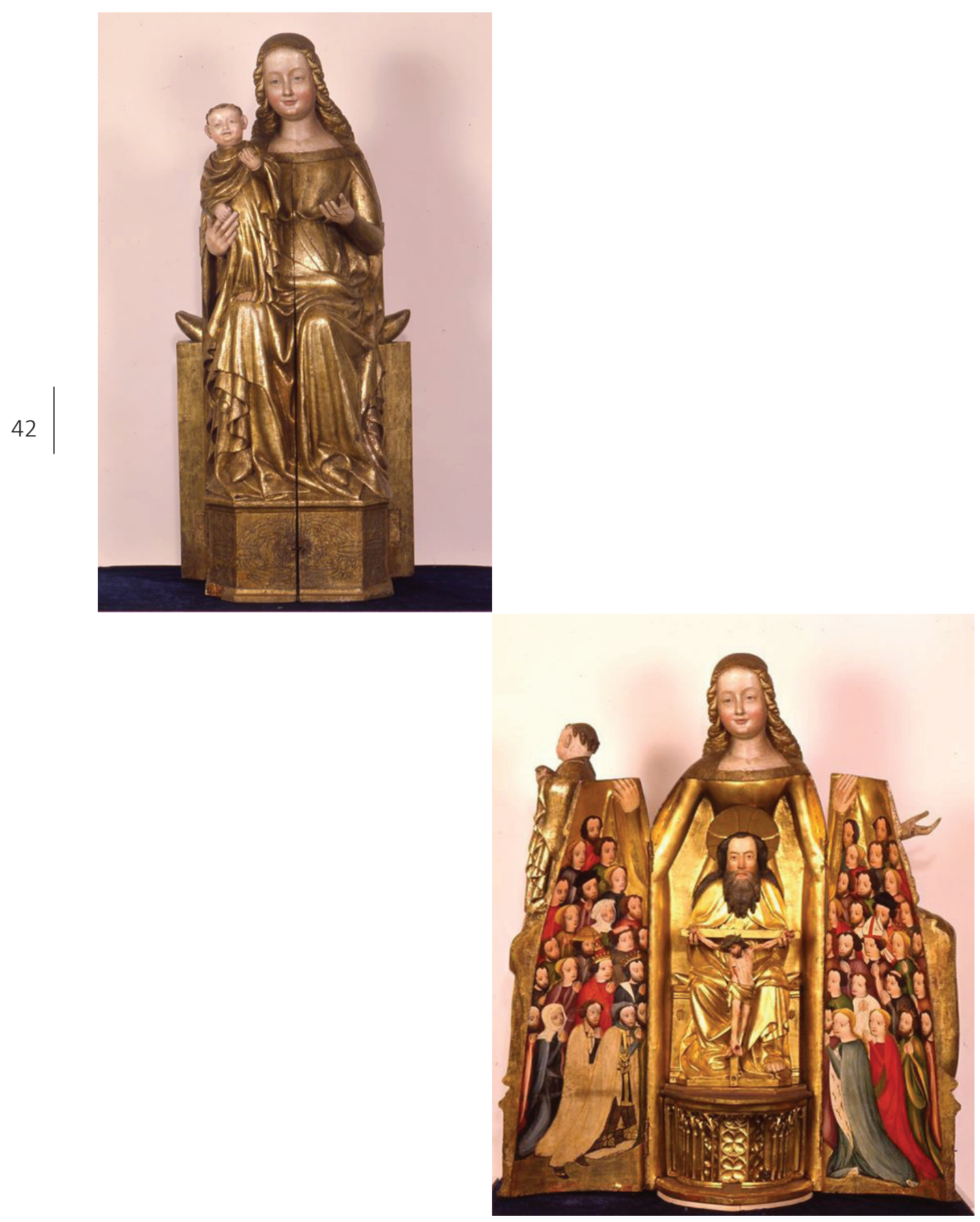

Figure 2. Schreinmadonna, from the Church of St Mary in Elbing (Elbląg, Poland), c. 1400 (open and closed). Now housed at the Ostpreußisches Landesmuseum, Lüneburg. Image used with permission 


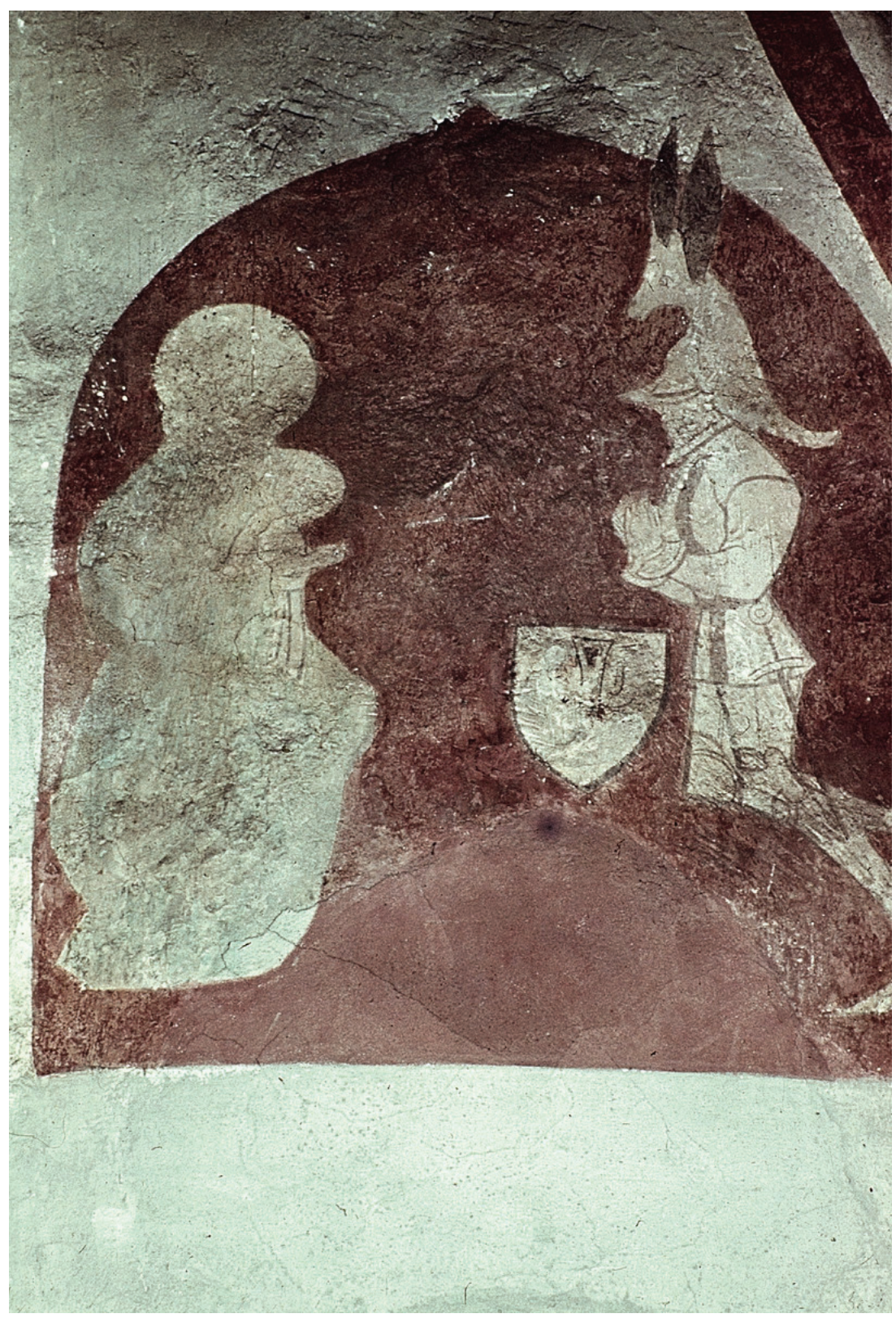

Figure 3. Fresco of a Teutonic Knight kneeling before the Virgin Mary. Juditten Church, Königsberg, c. 1390-1400. Image photographed c. 1940. Image Credit: Rudolf Schulze-Marburg, Zentralinstitut für Kunstgeschichte, Farbdiaarchiv 


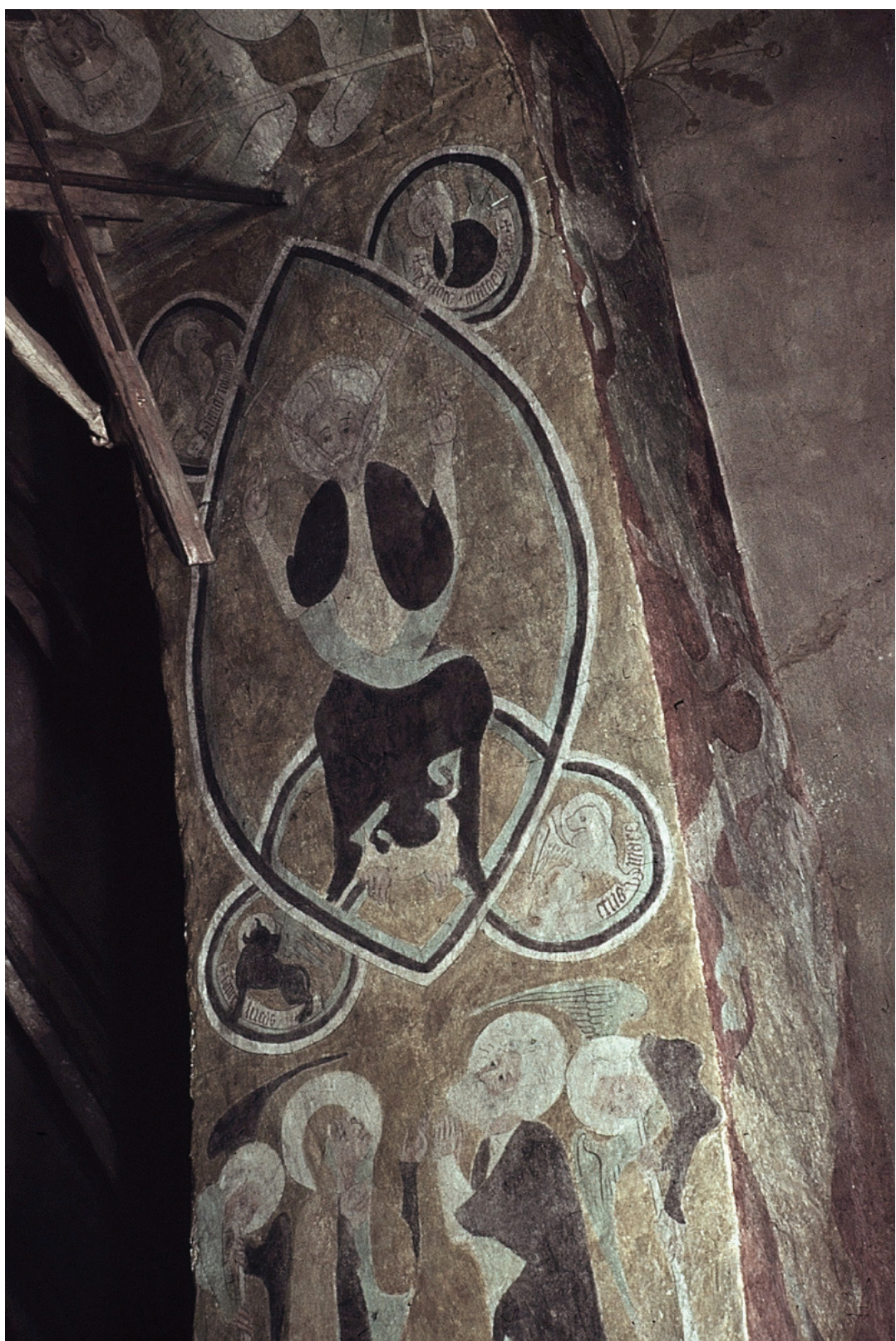

Figure 4. Fresco of Christ Enthroned, Juditten Church, Königsberg, c. 1390-1400. Image photographed c. 1940. Image Credit: Rudolf Schulze-Marburg, Zentralinstitut für Kunstgeschichte, Farbdiaarchiv 


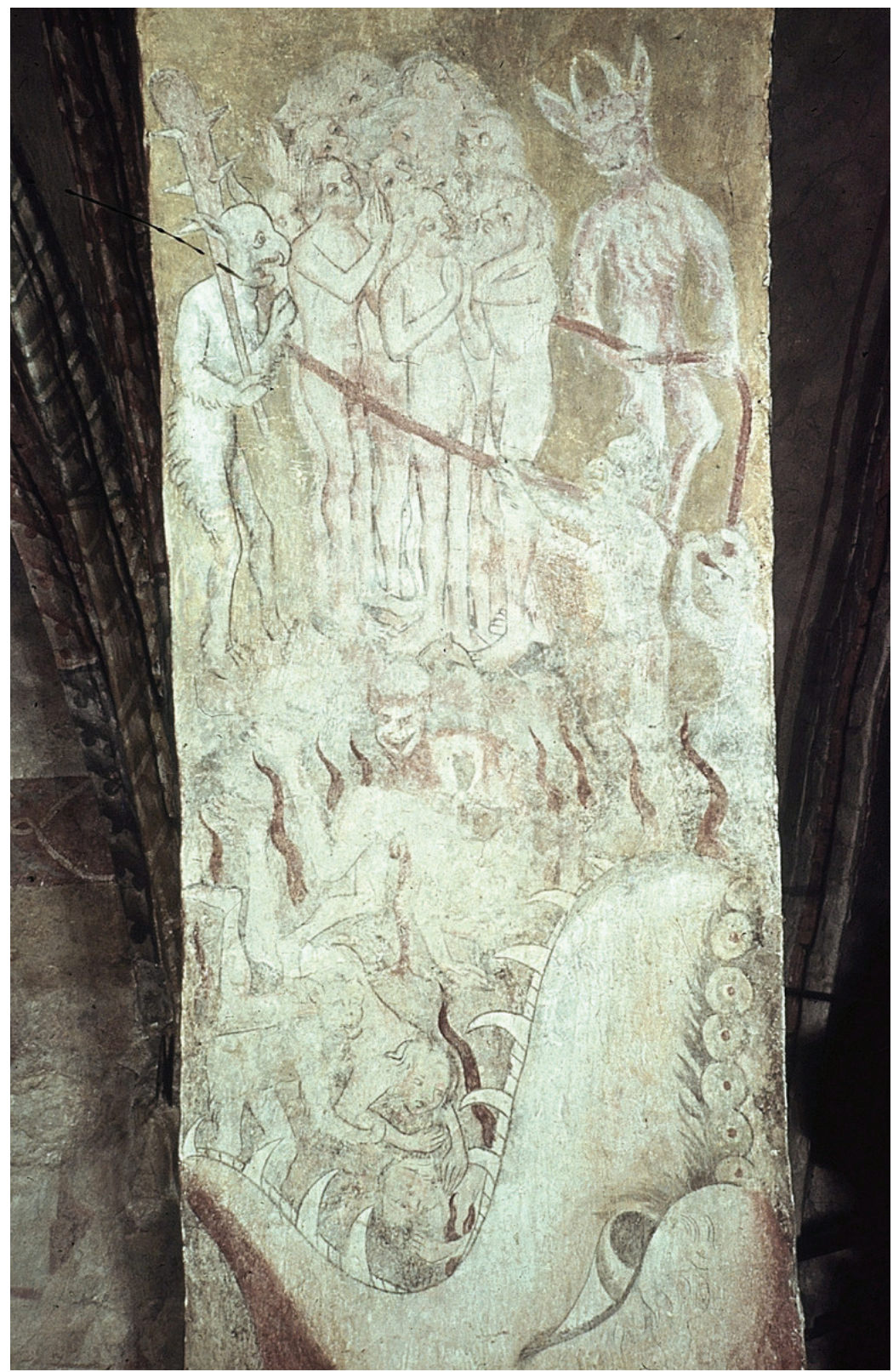

Figure 5. Fresco of the Apocalypse, Juditten Church, Königsberg, c. 1390-1400. Image photographed c. 1940. Image Credit: Rudolf Schulze-Marburg, Zentralinstitut für Kunstgeschichte, Farbdiaarchiv 
Other reminders dotted the walls of the small pilgrimage church at Juditten that further frame the understanding and representation of holy war in the 15th century. Similar to the southern portal of the Chapel of St Anne at Marienburg, showing the Apocalypse, at Juditten there was also a fresco depicting this on the southern side of the main archway in the church, facing an image of Christ enthroned, in this sense reflecting a connection between the depiction of Mary discussed above with the imagery of the Apocalypse. [Figure 4-5] Interestingly enough, there do not appear to be any depictions of the enemies, thus bringing into question the practice of actually depicting the Lithuanian or Žemaitijan enemies in the visual culture of the Order. Indeed, the apocalyptic imagery of the churches suggests instead an eschatological understanding of the wars as conflicts between Christianity and paganism, good and evil, God and the devil, as opposed to ethnic conflicts. In this light, the continued expeditions against the Žemaitijans take on an apocalyptic tone in the Order's visual culture. This was a common way of portraying the Order's struggle against the Prussians and Lithuanians, as has been suggested by Stefan Kwiatkowski's discussion of the inner life of the brethren, and Janusz Trupinda's analysis of the image programme of the Chapel of St Anne in Marienburg. ${ }^{71}$ This imagery surely appears to carry over to the Order's more 'frontier-oriented' centres, namely Königsberg and its surrounding shrines, thus placing the largely diplomatic campaigns to convert and subjugate the Žemaitijans within a common framework of not just written communication, but also the visual realm, as well.

\section{Conclusion}

The above analysis has outlined some main trends and elements present in the correspondence between the Teutonic Order, Lithuania, and the princes and rulers of Christendom in the late 14th and early 15th century. After briefly tracing the idea of crusading in the 14th-century Baltic, some specific elements become clear that highlight the complexity of dealing with the campaigns to Žemaitija as traditional crusades. Instead, they could be described as 'holy wars', though it should also be noted that the conflicts were multi-faceted, diplomatic, and heavily focused on ideology. Particular themes that emerge are the obligation of those who support the

71 KWIATKOWSKI, Stefan. „Devotio antiqua“, ihr Niedergang und die geistigen Ursachen der religiösen Krise des Deutschen Ordens im Spätmittelalter. In Deutscher Orden 1190-1990. Hrsg. von Udo ARNOLD. Lüneburg, 1997, S. 107-130, especially S. 122-127; TRUPINDA, Janusz. Die Chronik von Peter von Dusburg als Quelle für die Interpretation der architektonischen Ausschmückung des sog. Kapitelsaals und der Schlosskapelle im Nordflügel des Hochschlosses in Marienburg. In Mittelalterliche Kultur und Literatur im Deutschordensland Preussen: Leben und Nachleben (Publikacji Centrum Mediewistycznego Wydziału Nauk Historycznych UMK, nr. I; Sacra Bella Septentrionalia, t. I). Hrsg. von Jarosław WENTA, Sieglinde HARTMANN, Gisela VOLLMANN-PROFE. Toruń, 2008, S. 513-527. 
Order to be reminded that doing so was important for the whole of Christianity, not just the conversion of the Žemaitijans or Lithuanians.

This places the conquests within the framework of the antemurale rhetoric that came to define the expressions of collective identities throughout the 15th and 16th centuries in Europe. In the case of Žemaitija, the importance of the ende der cristenheit theme was highlighted as an example of a possible attempt to frame these conquests within the earlier wars of the Order. The reason for this could perhaps be an attempt to garner support for these expeditions, which had lost their lustre following the defeat of the Teutonic Order at the Battle of Tannenberg. The ways that the letters rely on memory and 'taking to heart' the imagery of the appeals is an important insight into the Teutonic Order's communication of its self-image and corporate identity to external supporters. Presenting itself as on the edges of Christendom, fighting God's enemies, and deserving of the support of rulers and leaders of Europe highlights the creative elements of its diplomacy. It is clear that the language, rhetoric and imagery of holy war remained a significant element of the written culture within and outside of the Teutonic Order's.

Finally, and most novel of this paper, the messages certainly have a relationship to the material culture of the Ordens/and. In fact, the link between the apocalyptic imagery present in Königsberg cathedral and churches near Königsberg, especially Juditten, provide the opportunity to view the struggle for Žemaitija more along the lines of contemporaries, perhaps in an apocalyptic light. The support of these churches by participants on crusades to Lithuania and expeditions to Žemaitija after 1386 also highlights the quite literal relationship between the written messages in the Order's correspondence and its visual communication in these churches. This also applied to the experience of those who did participate in the expeditions to Žemaitija, if we are to accept the link between the iconography of the Schreinmadonnen that were created in the Ordensland near the end of the 14th and the beginning of the 15th century. That the objects were used on the battlefield, in addition to being housed in the pilgrimage churches of the Order, provides a fascinating link between the Žemaitijan campaigns, the Order's self-expression, and its reception by its supporters in Prussia, as demonstrated by the parallels between the painted figures of the Virgin Mary at Juditten with that of the Schreinmadonnen. The links between written, spoken and visual communication all reflect the complex interwoven narratives expressed by the Teutonic Order at the beginning of its decline in the early 15 th century. 


\section{Acknowledgement}

I offer my thanks to Dr. Alexander Baranov, Dr. Loïc Chollet, Prof. Dr hab. Roman Czaja, Dr. Sebastian Kubon, Prof. Dr hab. Krzysztof Kwiatkowski and Dr. Sergey Polekhov for their helpful suggestions and guidance in preparing this paper. I would also like to thank to anonymous reviewers for their helpful comments and suggestions.

\section{List of printed sources quoted in the article}

Avignonesische Quellen zur Geschichte des Ordenslandes (1342-1366) (Beilage zum Jahresbericht des Königlichen Gymnasiums zu Braunsberg, Nr. 3). Hrsg. von Arthur MOTZKI. Braunsberg, 1914. Codex diplomaticus Lithuaniae. Ed. by Eduardus RACZYŃSKI. Vratislaviae, 1845.

Codex Diplomaticus Prussicus. Urkunden-Sammlung zur ältern Geschichte Preussens. Bd. 3-6. Hrsg. von Johannes VOIGT. Königsberg, 1848-1861.

Codex epistolaris Vitoldi magni ducis Lithuaniae 1376-1430 (Monumenta medii aevi historica res gestas Poloniae illustrantia, t. VI). Ed. Antonii PROCHASKA. Cracoviae, 1882.

Kodeks dyplomatyczny katedry i diecezji wileńskiej. T. 1. Wyd. Jan FIJAŁEK, Władysław SEMKOWICZ. Kraków, 1932.

Liv-, Esth- und Curländisches Urkundenbuch. Bd. 4. Hrsg. von Friedrich Georg von BUNGE. Reval, 1859. Das Marienburger Tresslerbuch der Jahre 1399-1409. Hrsg. von Erich JOACHIM. Königsberg, 1896.

Preußisches Urkundenbuch. Politisches (allgemeine) Abteilung. Bd. I. 2. Hälfte. Hrsg. von August SERAPHIM. Königsberg, 1909.

Rechnungen über Heinrich von Derby's Preussenfahrten 1390-91 und 1391. Hrsg. von Hans PRUTZ. Leipzig, 1893.

Scriptores rerum Prussicarum. Die Geschichtsquellen der Preussischen Vorzeit bis zum Untergange der Ordensherrschaft. Bd. 1-3. Hrsg. von Theodor HIRSCH, Max TÖPPEN, Ernst STREHLKE. Leipzig, 1861-1866.

Die Statuten des Deutschen Ordens. Hrsg. von Max PERLBACH. Halle, 1890.

Tabulae Ordinis Theutonici: ex tabularii regii Berolinensis codice potissimum. Ed. Ernestus STREHLKE. Berolini, 1869

Urkundenbuch des Bisthums Samland. Hf. 1. Hrsg. von Carl Peter WOELKY, Hans MENDTHAL. Leipzig, 1891.

List of previous studies quoted in the article

BARONAS, Darius; ROWELL, S.C. The Conversion of Lithuania. From Pagan Barbarians to Late Medieval Christians. Vilnius, 2015.

BAUMER, Christoph. Die Schreinmadonna. Marian Library Studies, 1978, vol. 9, art. 6, pp. 237-272.

BIRD, Jessalynn. Preaching and Crusade Memory. In Remembering the Crusades and Crusading. Ed. by Megan CASSIDY-WELCH. London, New York, 2017, pp. 13-33.

BONTEA, Cornel. Comment Reconquérir la Terre Sainte? L'Exemple du Memoria et Via at Terram Sanctam. Medieval and Early Modern Studies for Central and Eastern Europe, 2016, vol. 8, p. 123-143.

CASSIDY-WELCH, Megan. Before trauma: the crusades, medieval memory and violence. Continuum. Journal of Media \& Cultural Studies, 2017, vol. 31, no. 5, pp. 619-627.

CASSIDY-WELCH, Megan. The Stones of Damietta: Remembering the Fifth Crusade. In Papacy, Crusade, and Christian-Muslim Relations. Ed. by Jessalynn BIRD. Amsterdam, 2018, pp. 195-210.

CHOLLET, Loïc. Croisade ou évangélisation? La polémique contre les Chevaliers Teutoniques à l'aune des témoignages des voyageurs français de la fin du Moyen-Âge. Ordines Militares. Colloquia Torunensia Historica, 2015, t. 20, p. 175-203. 
CHOLLET, Loïc. Les Sarrasins du Nord. Une histoire de la croisade balte par la littérature (XIIe - XVe siècles). Neuchâtel, 2019.

CHOLLET, Loïc. Von Friedenverträgen bis zum Konzil von Konstanz (1414-1418): Schemaiten und die rechtliche Stellung von heidnischen Völkern. In Od traktatu kaliskiego do pokoju oliwskiego. Polsko-krzyżacko-pruskie stosunki dyplomatyczne $w$ latach 1343-1660 = Vom Frieden von Kalisch bis zum Frieden von Oliva. Diplomatische Beziehungen zwischen dem Königreich Polen und dem Deutschen Orden /Herzogtum Preußen in den Jahren 1343-1660. Red. Almut BUES, Janusz GRABOWSKI, Jacek KROCHMAL, Grischa VERCAMER, Hubert WAJS. Warszawa, 2014, s. 227-240.

CZAJA, Roman. Das Selbstverständnis der geistlichen Ritterorden im Mittelalter: Bilanz und Forschungsperspektive. In Selbstbild und Selbstverständnis der geistlichen Ritterorden (Ordines militares, vol. 13). Hrsg. von Roman CZAJA, Jürgen SARNOWSKY. Toruń, 2005, S. 7-21.

DIDRON, Édouard. Étude sur les images ouvrantes: et la vierge en ivoire du Louvre. Paris, 1870.

EHLERS, Axel. Die Ablaßpraxis des Deutschen Ordens im Mittelalter (Quellen und Studien zur Geschichte des Deutschen Ordens, Bd. 64). Marburg, 2007.

EHLERS, Axel. The Crusade of the Teutonic Knights against Lithuania Reconsidered. In Crusade and Conversion on the Baltic Frontier, 1150-1500. Ed. by Alan V. MURRAY. Farnham, 2001, pp. 21-44.

EMERY, Anthony. Malbork Castle - Poland. The Castle Studies Group Journal, 2007-2008, no. 21, pp. 138-156.

ERDMANN. Carl. The Origin of the Idea of Crusade. Princeton, 1977.

FRIES, Walter. Die Schreinmadonna. Anzeiger des Germanischen Nationalmuseums. Jhg. 1928 und 1929. Nürnberg, 1929, S. 5-69.

GUARD, Timothy. Chivalry, Kingship and Crusade. The English Experience in the Fourteenth Century. Woodbridge, 2013.

HERRMANN, Christofer. Der Hochmeisterpalast auf der Marienburg. Konzeption, Bau und Nutzung der modernsten europäische Fürstenresidenz um 1400 (Berliner Beiträge zur Bauforschung und Denkmalpflege, Bd. 17). Petersberg, 2019.

HOUSLEY, Norman. Contesting the Crusades. Oxford, 2006.

KREEM, Juhan. Crusading Traditions and Chivalric Ideals: The Mentality of the Teutonic Order in Livonia at the Beginning of the Sixteenth Century. Crusades, 2003, vol. 12, pp. 233-250.

KRUMBHOLTZ, Robert. Samaiten und der Deutsche Orden bis zum Frieden am Melno-See. Königsberg, 1890. KUBON, Sebastian. Die Außenpolitik des Deutschen Ordens unter Hochmeister Konrad von Jungingen (1393-1407) (Nova Mediaevalia, Bd. 15). Göttingen, 2016.

KWIATKOWSKI, Krzysztof. Die „Eroberung Preußens" durch den Deutschen Orden - ihr Bild und ihre Wahrnehmung in der Literatur des Deutschen Ordens im 14. Jahrhundert. In Kryžiaus karu epocha Baltijos regiono tauty istorinejje sq̨moneje. Sud. Rita Regina TRIMONIENĖ, Robertas JURGAITIS. Šiauliai, 2007, p. 142-154.

KWIATKOWSKI, Krzysztof. Zakon niemiecki jako „corporatio militaris". Część I: Korporacja i krąg przynależących do niej. Kulturowe i społeczne podstawy działalności militarnej zakonu w Prusach (do poczq̨tku XV wieku). Toruń, 2012.

KWIATKOWSKI, Stefan. "Devotio antiqua“, ihr Niedergang und die geistigen Ursachen der religiösen Krise des Deutschen Ordens im Spätmittelalter. In Deutscher Orden 1190-1990. Hrsg. von Udo ARNOLD. Lüneburg, 1997, S. 107-130.

LEIGHTON, Gregory. Did the Teutonic Order create a sacred landscape in thirteenth-century Prussia? Journal of Medieval History, 2018, vol. 44, no. 4, pp. 457-483.

LEIGHTON, Gregory. Reysa in laudem Dei et virginis Marie contra paganos: The Experience of Crusading in Prussia during the Thirteenth and Fourteenth Centuries. Zeitschrift für OstmitteleuropaForschung, 2020, 69. Jhg., Hf. 1, S. 1-25.

MAASING, Madis. Infidel Turks and Schismatic Russians in Late Medieval Livonia. In Fear and Loathing in the North: Jews and Muslims in Medieval Scandinavia and the Baltic Region. Ed. by Cordelia HESS, Jonathan ADAMS. Berlin, Boston, 2015, pp. 347-388. 
MASCHKE, Erich. Burgund und der preußische Ordensstaat. Ein Beitrag zur Einheit der ritterlichen Kultur Europas im Spätmittelalter. In MASCHKE Erich. Domus Hospitalis Theutonicorum. Europäische Verbindungslinien der Deutschordensgeschichte. Gesammelte Aufsätze aus den Jahren 19311963 (Quellen und Studien zur Geschichte des Deutschen Ordens, Bd. 10). Bonn, 1970, S. 15-34.

MURRAY, Alan V. The Saracens of the Baltic: Pagan and Christian Lithuanians in the Perception of English and French Crusaders to Late Medieval Prussia. Journal of Baltic Studies, 2010, vol. 41, no. 4, pp. 413-429.

NÖBEL, Wilhelm. Das Problem der Einrichtung der Ordensvogtei Samaiten. Zeitschrift für Ostforschung, 1968, 17. Jhg., Hf. 4, S. 692-697.

PARAVICINI, Werner. Die Preußenreisen des europäischen Adels. Teile 1-2 (Beihefte der Francia, Bd. 17/1, 17/2). Sigmaringen, 1989-1995.

PARAVICINI, Werner. Verlorene Denkmäler europäischer Ritterschaft: Die heraldischen Malereien des 14. Jahrhunderts im Dom zu Königsberg. In Kunst und Geschichte im Ostseeraum: Tagungen 1988 und 1989 (Homburger Gespräche, Hf. 12). Hrsg. von Erich BÖCKLER. Kiel, 1990, S. 67-168.

PETRAUSKAS, Rimvydas. Litauen und der Deutsche Orden: vom Feind zum Verbündeten. In Tannenberg - Grunwald - Žalgiris 1410: Krieg und Frieden im späten Mittelalter (Deutsches Historisches Institut Warschau. Quellen und Studien, Bd. 26). Hrsg. von Werner PARAVICINI, Rimvydas PETRAUSKAS, Grischa VERCAMER. Wiesbaden, 2012, S. 237-252.

RAUTENBERG, Wilhelm. Einwirkungen Böhmens auf die Geschicke des Ordenslandes Preußen im späten Mittelalter. Zeitschrift für Ostforschung, 1973, 22. Jhg., Hf. 4, S. 626-695.

SARNOWSKY, Jürgen. Identität und Selbstgefühl der geistlichen Ritterorden. In Ständische und religiöse Identitäten in Mittelalter und frühen Neuzeit. Hrsg. von Stefan KWIATKOWSKI, Janusz MAŁŁEK. Toruń, 1998, S. 109-130.

SARNOWSKY, Jürgen. The Military Orders and Crusading in the Fifteenth Century: Perception and Influence. In Reconfiguring the Fifteenth-Century Crusade. Ed. by Norman HOUSLEY. London, 2017, pp. 123-160.

SCHLEIF, Corine. Die Schreinmadonna im Diözesanmuseum zu Limburg. Ein verfemtes Bildwerk des Mittelalters. Nassauische Annalen. Jahrbuch des Vereins für Nassauische Altertumskunde und Geschichtsforschung, 1984, vol. 95, S. 39-54.

SEYDEL, Walter. Mittelalterliche Wandmalereien im Chor des Domes zu Königsberg Pr. Königsberg, 1930. SPENCER, Stephen J. Feelings of betrayal and echoes of the First Crusade in Odo of Deuil's De profectione Ludovici VII in Orientem. Historical Research, 2019, vol. 92, no. 258, pp. 657-679.

SRODECKI, Paul. Antemurale-based frontier identities in East Central Europe and their ideological roots in medieval/early modern alterity and alienity discourses. In Collective Identity in the Context of Medieval Studies. Ed. by Michaela ANTONÍN MALANÍKOVÁ, Robert ANTONÍN. Ostrava, 2016, pp. 97-120.

SRODECKI, Paul. «Murus et antemurale pollens et propugnaculum tocius christianitatis.» Der Traktatenstreit zwischen dem Deutschen Orden und dem Königreich Polen auf dem Konstanzer Konzil. Schweizerische Zeitschrift für Religions- und Kulturgeschichte, 2015, 109. Jhg., S. 47-67.

SRODECKI, Paul. Schilt der Cristenheite i Scutum christianitatis - spory polsko-krzyżackie a retoryka przedmurza / tarczy na początku XV wieku. In Unia w Horodle na tle stosunków polsko-litewskich od Krewa do Zaręczenia wzajemnego Obojga Narodów. Red. Sławomir GÓRZYŃSKI. Warszawa, 2015, s. 147-163.

SRODECKI, Paul. Władysław III and the Polish-Hungarian Bulwark topoi against the Background of the Ottoman Threat in the 15th Century. In Hungaro-Polonica. Young Scholars on Medieval PolishHungarian Relations. Ed. by Dániel BAGl, Gábor BARABÁS, Zsolt MÁTÉ. Pécs, 2016, pp. 327-356.

STORCH, Ernst Ludwig. Die Kirche und das Kirchspiel Juditten im Landkreise Königsberg. Ein Beitrag zur vaterländischen, Kirchen- und Kultur-Geschichte Preußens. Königsberg, 1861.

STRENGA, Gustavs. Remembering the Common Past: Livonia as a lieu de mémoire of the Teutonic Order in the Empire. In Livland - eine Region am Ende der Welt? Forschungen zum Verhältnis zwi- 
schen Zentrum und Peripherie im späten Mittelalter (Quellen und Studien zur baltischen Geschichte, Bd. 27). Hrsg. von Anti SELART, Matthias THUMSER. Köln, Weimar, Wien, 2017, S. 347-370.

THUMSER, Matthias. Ein neue Aufgabe im Heidenkampf? Pläne mit dem Deutschen Orden als Vorposten gegen die Türken. In Europa und die Türken in der Renaissance (Frühe Neuzeit, Bd. 54). Hrsg. von Bodo GUTHMÜLLER, Wilhelm KÜHLMANN. Tübingen, 2000, S. 139-176.

TRUPINDA, Janusz. Die Chronik von Peter von Dusburg als Quelle für die Interpretation der architektonischen Ausschmückung des sog. Kapitelsaals und der Schlosskapelle im Nordflügel des Hochschlosses in Marienburg. In Mittelalterliche Kultur und Literatur im Deutschordensland Preussen: Leben und Nachleben (Publikacji Centrum Mediewistycznego Wydziału Nauk Historycznych UMK, nr. I; Sacra Bella Septentrionalia, t. I). Hrsg. von Jarosław WENTA, Sieglinde HARTMANN, Gisela VOLLMANN-PROFE. Toruń, 2008, S. 513-527.

URBAN, William. The Teutonic Knights and Baltic Chivalry. The Historian, 1994, vol. 56, no. 3, pp. 519-530.

VERCAMER, Grischa. Zeit in Peters von Dusburg Chronica terre Prussie (1326). Chronologische Ordnung oder Mittel zum Zweck? Zapiski Historyczne, 2011, t. 74, z. 4, s. 517-533.

VILLADS JENSEN, Kurt. Physical extermination of physical sin - Remarks on theology and mission in the Baltic region around 1200. In Sacred Space in the State of the Teutonic Order in Prussia (Publikacji Centrum Mediewistycznego Wydziału Nauk Historycznych UMK, nr. V; Sacra Bella Septentrionalia, t. II). Ed. by Jarosław WENTA, Magdalena KOPCZYŃSKA. Toruń, 2013, pp. 87-99.

VOIGT, Johannes. Geschichte Preussens, von den ältesten Zeiten bis zum Untergange der Herrschaft des Deutschen Ordens. Bd. 7: Die Zeit vom Hochmeister Ulrich von Jungingen 1407 bis zum Tode des Hochmeisters Paul von Rußdorf 1441. Königsberg, 1836.

VOIGT, Johannes. Namen-Codex der Deutschen Ordens-Beamten, Hochmeister, Landmeister, Großgebietiger, Komthure, Vögte, Pfleger, Hochmeister-Kompane, Kreuzfahrer und Söldner-Hauptleute in Preussen. Königsberg, 1843.

WEISE, Erich. Der Heidenkampf des Deutschen Ordens. Erster Teil. Zeitschrift für Ostforschung, 1963, 12. Jhg., Hf. 3, S. 420-473.

WüST, Marcus. Studien zum Selbstverständnis des Deutschen Ordens im Mittelalter (Quellen und Studien zur Geschichte des Deutschen Ordens, Bd. 73). Weimar, 2013.

\title{
KRYŽIAUS ŽYGIAI IR ŠVENTASIS KARAS VOKIEČIŲ ORDINO KOVOJE DĖL ŽEMAITIJOS: RAŠYTINĖ IR VIZUALIOJI PERSPEKTYVOS
}

\author{
Gregory Leighton
}

\section{Santrauka}

XIV a. pabaigos - XV a. pradžios rašytinėje korespondencijoje tarp Vokiečiu ordino, Lietuvos Didžiosios Kunigaikštystės ir kitų krikščioniškų šalių valdovų, kurioje aptarinèti bandymai užkariauti Žemaitiją, straipsnio autorius ieškojo kryžiaus žygių ir šventojo karo retorikos bei vaizduotès tęstinių ir unikalių bruožų. Padalyta ị tris dalis publikacija pradedama kryžiaus žygių idejjos tęstinumo Baltijos regione XIV a. aptarimu, kuris ypač atsiskleidžia per specifinių terminų, tokių kaip „piligrimai“ (peregrinus), ir kitų reiškinių, susijusių su kryžiaus žygių judejjimu, perèmimą. Tačiau kartu autorius apibūdina specifinius elementus, kurie parodo, kad i Žemaitijoje vykusias kampanijas sudètinga žiūrèti kaip i tradicinius kryžiaus žygius. Karinès ekspedicijos i Žemaitiją, veikiau suvoktinos kaip „„̌̌ventasis karas“, nors ir prie tokios 
traktuotės tenka pridurti, jog konfliktas buvo daugialypis, ne tik karinio pobūdžio, bet ir diplomatinis, ir labai didelę reikšmę teikęs ideologijai. Iš to atsirado siužetų, turèjusių priminti tiems, kurie palaikè Vokiečių ordino pastangas, kad šitoks palaikymas buvo svarbus visam krikščioniškajam pasauliui, ne tik žemaičių ar lietuvių atvertimui.

Nuo šios analizès straipsnyje toliau pereinama prie XV a. Vokiečių ordino susirašinèjimo su jo rẻmėjais Europoje. Atsižvelgiant i pirmojoje dalyje prieitas išvadas, čia sugestijuojama, kad karas Žemaitijoje buvo suvokiamas antemurale christianitatis (krikščionybès gynimo) XV-XVI a. Europoje kontekste. Žemaitijos atveju buvo svarbus ir buvimo krikščionijos pakraštyje (ende der cristenheit) siužetas, kuris tẻra vienas pavydžių, rodančių, kad Žemaitijos užkariavimą bandyta konceptualizuoti kaip ankstesnių Ordino karų, konkrečiai jo užkariavimų Prūsijoje, tąsą. Pagrindinè tokio elgesio priežastis, matyt, buvo siekis suformuoti paramą ekspedicijoms, kurios jau buvo netekusios savo šlovès po $1410 \mathrm{~m}$. liepos 15 d. Vokiečių ordino sutriuškinimo Žalgirio mūšyje. Tai, kaip korespondencijoje pasikliaujama atminimi ir kaip „imama j širdi”“ kreipimuose atsiskleidžianti vaizduotè, yra svarbūs liudijimai to, kaip Vokiečiu ordinas išoriniams sajungininkams krikščioniškajame pasaulyje perteikè savo korporatyvinę tapatybę ir savivaizdị. Tai, kad Vokiečių ordinas savo veiklą vaizdavo kaip veiklą „krikščionijos pakraštyje“, kovą su Dievo ir Bažnyčios priešais, kuri nusipelnè Europos krikščioniškujų valdovų paramos, rodo, jog diplomatijos ir strategijos srityje Ordinas elgèsi kūrybiškai.

Galiausiai - ir tai yra novatoriškiausia šio straipsnio dalis - būta ryšio tarp aptartuju ideologinių žinučių ir Vokiečių ordino valdų Prūsijoje materialiosios kultūros. Straipsnyje bandoma išryškinti šių žinučių ir laikotarpio vizualiosios kultūros ryšius - klausimą, kuris ligšioliniuose tyrimuose beveik neliestas. Autorius parodo ryšị tarp apokaliptinès vaizduotès, kuri atsiskleidžia Karaliaučius katedroje ir kitose bažnyčiose aplink Karaliaučių, ypač Judyčių bažnyčioje, ištapytose freskose, ir Vokiečių ordino retorikos, skirtos atvykusiems kryžininkams. Tai suteikia galimybę priartinti mūsų žvilgsni prie to meto amžininkų požiūrio i Žemaitijos užkariavimus ir galbūt i juos žiūrèti net besiartinančios apokalipsès kontekste. Iš tiesų kryžininkų, kurie vyko j kryžiaus žygius Lietuvoje ir i ekspedicijas Žemaitijoje, parama šioms bažnyčioms (įskaitant Karaliaučiaus katedrą) dar ir po 1386 m. rodo gana tiesioginį ryši tarp rašytinių žinučių, kurias aptinkame Vokiečių ordino korespondencijoje, ir jų vizualiojo komunikavimo šiose bažnyčiose. Taigi, žiūrèdami j̨ konkrečius objektus, galime susidaryti aiškesnị vaizdą apie tų, kurie dalyvavo ekspedicijose į Žemaitiją, patirtis. Būtent per šią prizmę straipsnyje atskleidžiamas ryšys tarp Vokiečių ordino valdose Prūsijoje XIV a. pačioje pabaigoje ir XV a. pradžioje sukurtų Mergelès Marijos medinių skulptūrų su atveriamais elementais (Schreinmadonna) ikonografijos ir vaizduotès, kurios kontūrus matome kryžininkų laiškuose. Faktas, kad tokie objektai buvo ne tik eksponuojami piligrimų prieš žygi i Žemaitiją arba po jo lankytose bažnyčiose Vokiečių ordino valdose, bet ir naudoti mūšio lauke, leidžia kalbèti apie nepaprastai ịdomų ryšį tarp karo ekspedicijų i̇ Žemaitiją, Vokiečių ordino saviraiškos ikonografijos bandymų ir šios saviraiškos recepcijos Ordino rèmèju gretose. Tą ypač atskleidžia paralelès tarp Mergelès Marijos nutapytos figūros Judyčių bažnyčioje ir Elbingo Madonos medinès figūros (Schreinmadonna) ikonografijos, kuri sukurta tarp 1390 ir 1400 m. Tyrimas rodo, kad šventojo karo retorika ir vaizduotè liko reikšmingi tiek rašytinės, tiek vizualinės kultūros elementai ir Vokiečių ordino valdose, ir už jų ribų. 